NBER WORKING PAPER SERIES

\title{
TRADABILITY, PRODUCTIVITY, AND UNDERSTANDING INTERNATIONAL ECONOMIC INTEGRATION
}

\author{
Paul R. Bergin \\ Reuven Glick \\ Working Paper 11637 \\ http://www.nber.org/papers/w11637 \\ NATIONAL BUREAU OF ECONOMIC RESEARCH
1050 Massachusetts Avenue
Cambridge, MA 02138
September 2005
}

We thank seminar participants at the London School of Economics, University Pompeu Fabra, University Autonoma Barcelona, European Central Bank, Institute for Advanced Studies in Vienna, Birkbeck College, the University of California at Berkeley, and the Annual Meetings of the American Economic Association. The views expressed below do not represent those of the Federal Reserve Bank of San Francisco or the Board of Governors of the Federal Reserve System. Part of this research was undertaken while Bergin was a Jean-Monet Fellow at the European University Institute. The views expressed herein are those of the author(s) and do not necessarily reflect the views of the National Bureau of Economic Research.

(C2005 by Paul R. Bergin and Reuven Glick. All rights reserved. Short sections of text, not to exceed two paragraphs, may be quoted without explicit permission provided that full credit, including $\odot$ notice, is given to the source. 
Tradability, Productivity, and Understanding International Economic Integration

Paul R. Bergin and Reuven Glick

NBER Working Paper No. 11637

September 2005

JEL No. F4

\title{
$\underline{\text { ABSTRACT }}$
}

This paper develops a two-country macro model with endogenous tradability to study features of international economic integration. Recent episodes of integration in Europe and North America suggest some surprising observations: while quantities of trade have increased significantly, especially along the extensive margin, price dispersion has not decreased and may even have increased. We propose a way of reconciling these price and quantity observations in a macroeconomic model where the decision of heterogeneous firms to trade internationally is endogenous. Trade is shaped both by the nature of heterogeneity -- trade costs versus productivity -and by the nature of trade policies -- cuts in fixed costs versus cuts in per unit costs like tariffs. For example, in contrast to tariff cuts, trade policies that work mainly by lowering various fixed costs of trade may have large effects on entry decisions at the extensive margin without having direct effects on price-setting decisions. Whether this entry raises or lowers overall price dispersion depends on the type of heterogeneity that distinguishes the new entrants from incumbent traders.

\author{
Paul R. Bergin \\ Department of Economics \\ University of California at Davis \\ One Shields Avenue \\ Davis, CA 95616 \\ and NBER \\ prbergin@ucdavis.edu \\ Reuven Glick \\ Economic Research Department \\ Federal Reserve Bank of San Francisco \\ 101 Market Street \\ San Francisco, CA 94105 \\ reuven.glick@sf.frb.org
}




\section{Introduction}

International macroeconomics is interested in the issue of market segmentation and integration for several reasons. Firstly, the broad literature on pricing to market and deviations from purchasing power parity relies upon the assumption that national markets are segmented, so that firms have the ability to charge different prices in different countries. Secondly, such failures in the law of one price are fundamental to our theories of real exchange rate behavior. Thirdly, given recent policies aimed at promoting international market integration in Europe and North America, there is heightened interest in understanding the implications of such integration policies.

Recent experiences with policy reforms have provided some new evidence regarding market segmentation which is difficult for our standard open economy macro models to explain. In particular, we refer to the Canada-U.S. Trade Agreement (CUSTA) and the North America Free Trade Agreement (NAFTA) aimed at promoting economic integration in North America in the early 1990s, and the Single Market Program (SMP) in the early 1990s and the European Monetary Union (EMU) in 1999 designed to further consummate economic integration in Europe. One set of observations involves quantities: trade volume seems to respond more significantly than standard models predict, and much of the increased trade volume occurs in the form of new goods that were not previously traded, rather than increased intensity in trade of previously traded goods (Kehoe and Ruhl, 2002). This is often referred to as the extensive margin of trade. A second set of observations refers to prices. Recent research by Engel and Rogers (2004) suggests that average deviations from the law of one price deviations for many groups of traded goods in Europe stopped converging in 1999 and may even be diverging. A similar conclusion is suggested in other research for North America, where price convergence appears to have stopped in the early 1990s, with divergence in many classes of traded goods.

These price and quantity observations present a challenge to our standard models of international integration, and this paper proposes a way of reconciling them. It provides an illustration of how macro models that endogenize firms' decisions to trade can be useful. The results also shed a new light on the debate over how best to measure the degree of international integration: in terms of trade quantities or prices.

In general, our open economy macro models are ill-suited for studying the process of economic integration, since they tend to take market segmentation as given, simply assuming firms can set different prices in different national markets. Standard trade theory also has difficulty here. Recent advances have been made in modeling the costs of trade, and how they determine the decision of firms to export (see Melitz, 2003; Ghironi and Melitz, 2004; Kehoe and Ruhl, 2002; and Ruhl 2003). Emphasis in this literature has been placed on heterogeneity of firms in terms of productivities, where only the more productive firms find it profitable to enter the export market. But uniform trade costs in such models imply that there is a uniform price

wedge for goods across countries. However, evidence indicates that there is a great deal of 
heterogeneity in price wedges (Crucini, Telmer, and Zachariadis, 2001), as well as in the trade costs that drive them (Hummels, 1999, 2001; Anderson and van Wincoop, 2003). To address this fact, we emphasize the role of heterogeneity in the trade cost dimension.

To be more precise, this paper formulates a two-country macro model where each country has a continuum of monopolistically competitive producers which must choose whether to sell in the foreign market in addition to the domestic market. This decision is affected by two types of real trade frictions: one in the form of per-unit (iceberg) trade costs which can vary by good, and the other a fixed cost of international trade which does not depend upon the quantity traded and does not vary by good. The first type of cost is motivated by tariffs and transportation costs, as discussed above; the second type reflects establishment costs or the cost of learning to deal with a foreign language or legal system. While iceberg costs have been favored in recent macroeconomic studies of segmentation (Obstfeld and Rogoff, 2000), fixed costs are essential if some goods are to be nontraded under the assumption of monopolistic competition. A firm will participate in the international market only if it can generate additional positive profits by doing so. In equilibrium, the traded goods will be those with low trade costs or high productivity.

The paper's findings arise from two important distinctions raised by our model. First, what type of trade cost is the liberalization policy reducing: per unit costs like tariff rates or the various fixed costs of trade? Second, which of the two types of heterogeneity distinguishes new entrants into trade from incumbent traders: transport costs or productivity?

The first and most general theoretical finding of the paper is that it is incorrect to assume that policies promoting integration in terms of trade volume must also promote price convergence. If prices are set under monopolistic competition as a markup over per-unit costs, including per-unit trade costs for exports, then a policy that reduces per-unit tariffs indeed will have a direct impact in price-setting behavior in the foreign market and will reduce pricedispersion between the countries. But fixed costs do not enter the price-setting decision in a standard model of monopolistic competition, so policies working mainly through fixed costs of trade do not affect foreign prices here. Consequently, such trade policies may not reduce international price dispersion. The model also implies that these two types of policies have very different implications for quantities: with fixed cost reductions working much more strongly through the extensive margin of new goods not previously traded.

A second finding is that if new trade arises largely at the extensive margin, it may lead to the type of price dispersion observed recently. For example, suppose that goods are heterogeneous in terms of their per-unit trade costs such as transportation costs. Then the new goods being traded systematically will have higher per-unit costs than previously traded goods. After all, this is precisely the reason why these goods were previously nontraded. These will be goods with higher price wedges between national markets, and their entry into trade will raise the average international price wedge, and thereby a mean-squared error measure of price dispersion.

Section II presents empirical observations of recent trade liberalizations and other policies promoting greater economic integration in Europe and North America. Section III develops an 
open economy macro model with endogenous trade. Section IV discusses analytically how the model can be used to reconcile price and quantity observations, where Section V uses numerical simulations to address theoretical ambiguities. Section VI concludes by drawing implications for the recent experiences of Europe and North America, and by raising questions for future research.

\section{Empirical Observations}

\section{A. $\quad$ Price Evidence}

Foremost among the empirical observations we wish to highlight is the finding that trade liberalizations need not lead to convergence of price levels across national markets. There is an extensive and active literature measuring failures in the law of one price across national markets. One finding over much of this literature is that the law of one price fails also for tradable goods (Engel, 1999). Another is that there is a good deal of heterogeneity in the degree of price deviations at the disaggregated level, with about as many goods underpriced as overpriced (Crucini et. al, 2001).

The European case is especially surprising, given that an ostensible goal of monetary union was to promote price transparency and arbitrage. Of special interest here is recent research by Engel and Rogers (2004), who find that while there was price convergence within the Eurozone in the early to mid 1990s, there has been no convergence since the adoption of the euro in 1999. ${ }^{1}$ We replicate and extend this result in Figure 1 to include more recent data. The figure is constructed from price level data for individual goods from 1990-2004, using data from the Economist Intelligence Unit for about 100 traded as well as 38 nontraded items, covering 18 cities within the Eurozone. ${ }^{2}$ Data collectors at each location are given discretion to identify representative examples of particular classes of goods (such as women's cardigan sweaters or 100-count aspirin bottles) Since each observation is drawn from a potentially wide and evolving range of varieties available in the market, the prices can be affected by new entry. The EIU sales literature states that its price measures are affected by the opening up of markets and deregulation: “As governments welcome foreign investment and open up their markets to international companies, so the variety and availability of imported products improves.”

Following Engel and Rogers, the metric used in Figure 1 is the mean squared error of (the relative logs of) product item prices across cities in the Euro zone, averaged over groups of goods. The figure shows the changes in price dispersion for different product categories and

\footnotetext{
${ }^{1}$ This result is distinct from micro-level studies that find convergence to the law of one price in particular industries for narrowly defined goods, such as brands of autos and televisions (see Imbs et al., 2004; Goldberg and Verboven, 2005). It is also a distinct issue from the evident lack of convergence in European national inflation rates: for example, divergent inflation rates may still be associated with convergence in price levels if the higher rates of change are in countries that initially had low price levels. ${ }^{2}$ This data set is becoming widely used in the literature. In addition to Engel and Rogers (2004), see also Crucini and Shintani (2004) for a leading application.
} 
subperiods. ${ }^{3}$ One observation is the heterogeneity in price deviations among different categories of goods. But even more striking is that of the eight categories of traded goods, seven show greater price dispersion in the period since 1998. The fact that this finding continues to hold in our extended data set through 2004 indicates it is not just a temporary byproduct of transition, as prices were converted to new currency units at the onset of the monetary union.

Other recent papers support this general conclusion for Europe. The European Commission (2004) finds that price indices in the most expensive and least expensive countries were converging in the early 1990s, but stopped converging in the middle of the decade. Baye et al. (2002) examine the effects of EMU on a small set of homogenous goods that shoppers buy online, mostly electronic goods, and find that EMU had little effect on price dispersion. Lutz (2002) considers a small set of goods with only post-1999 price survey data and also finds that EMU has not reduced price dispersion significantly.

In our empirical investigation, we find that further insight is obtained by distinguishing between "core" and "peripheral" countries within the Euro zone, as reported in the top panel of Table 1, where we denote Finland, Ireland, Portugal, and Spain as peripheral countries, and Austria, Belgium, France, Germany, Italy, Luxemburg, and the Netherlands as the core countries. This distinction makes sense based on both geography and the extent to which lowered trade barriers have had time to foster stronger cross-country trade links. The former countries are located in the outer areas of Europe. Moreover, Ireland joined in 1973, Portugal and Spain in 1986, and Finland in 1995, well after the core members formed the European Union in $1957 .{ }^{4}$

Consistent with the message of Figure 1, the top panel of Table 1 shows that overall price dispersion for traded goods in Europe fell over the period 1990-94, was flat for 1994-1998, and then rose over 1998-2004 after the formal adoption of the euro. What is of main interest in Table 1 is that the increase in price dispersion during the latter period was greatest among the core countries. In fact, for these countries the increase in price dispersion since 1998 has almost fully offset the decline in price dispersion experienced in the early 1990s. In contrast, the peripheral countries experienced a much greater decline in price dispersion in the early 1990s and a much weaker increase in dispersion with core countries since adoption of the euro.

We also find similar conclusions for price integration when we examine the effects of trade liberalization in North America, following the CUSTA trade liberalizations between Canada and the U.S. in 1989, Mexico’s comprehensive trade liberalization and economic reforms begun in the late 1980s, and Mexico entering into NAFTA in $1994 .^{5}$ The bottom panel

\footnotetext{
${ }^{3}$ Engel and Rogers (2004) find that this result holds, even after controlling for relative wages, relative incomes, VAT taxes, slow adjustment of prices, etc

${ }^{4}$ Austria did not join the European Union until 1995, but is treated as a core country because of its longstanding trade links with Germany and its central geographic position within Europe.

${ }^{5}$ Although NAFTA entailed an immediate reduction in various tariffs and nontariff barriers when it was enacted in 1994, most of the trade reforms under the agreement involved gradual liberalization. Consequently, economic integration in North America has been a gradual process over an extended period of time..
} 
of Table 1 reports calculations of changes in price dispersion in North America based on EIU data for individual product items in 12 U.S. cities, 4 Canadian cities, and Mexico City. Price dispersion declined considerably in the early 1990s, but increased sharply after 1994 at the time of the adoption of NAFTA. ${ }^{6}$ While the Mexican crisis of 1994-95 most probably played a role in the upward movements involving Mexico, it does not explain why price dispersion between U.S. and Canada also rose.

Other studies support this finding of greater price dispersion in North American since the adoption of NAFTA. See Globerman and Storer (2003) for a more detailed discussion and analysis of this literature. In particular, Engel and Rogers (1998) find that any price convergence during the 1990s was not due to NAFTA. Further, since 1994 they found that cross-border price variability increased for some very tradable categories, such as clothing and footwear, where one would expect that trade liberalization should have been most likely to encourage price convergence.

The conclusion arising from these recent studies is that price convergence may be limited following policies encouraging integration, and furthermore, there even appears to be a tendency for price divergence in many tradable groups of goods. One possible explanation suggested by past theoretical literature is the presence of sticky goods prices and fluctuations in nominal exchange rates. Earlier work by Engel and Rogers (1996) found a role for such an explanation, but that accounts for less than half of the LOP deviations. Clearly, we need to find other types of sources for price deviations. Further, this explanation cannot explain increased price divergence across European country borders after the EMU eliminated currency fluctuations in 1999. A second possible explanation is that price convergence in Europe and North America stopped because goods market integration had been completed by that point and price convergence had reached its natural limit. However, the presence of price divergence rather than just a lack of convergence argues against this explanation. Further, evidence of significant additional goods market integration in terms of trade flows suggests that integration had not reached its limit previously. We turn to this quantity evidence next and draw additional lessons.

\section{B. Quantity Evidence}

Despite the lack of evidence of market integration in terms of price convergence, there does seem to be evidence that trade liberalization promotes integration in terms of increased trade volume. An important aspect of this finding is that much of the new trade is in the form of new goods not previously traded. Evidence of this extensive margin of trade is documented in Kehoe and Ruhl (2002), who study six different trade liberalizations, including the EU Single Market and NAFTA. They define growth at the extensive margin as growth in the share of

\footnotetext{
${ }^{6}$ Since the EIU data are only available from 1990 on, we were unable to examine earlier price dispersion movements within North America.
} 
exports by products accounting for 10 percent or less of total trade prior to liberalization. ${ }^{7}$ They find that initially these "least traded" product categories experienced the largest increases in export shares following trade liberalization.

For example, as shown in Table 2, European integration during the 1990s was associated with an increase in this share from 10 percent to 17 percent in the case of Sweden, 14 percent of Italy, and 19 percent of Portugal. Adjusting these results for the increase in total trade, one can compute that the external margin accounted for more than 100 percent of the increased trade of Sweden and Italy and almost 90 percent of that of Portugal with their EU trade partners. Extensive margin effects are significant in the case of NAFTA integration during the 1990s as well. The extensive margin share rose from 10 percent to 15 percent in the case of U.S. exports to Mexico and to 41 percent in the case of Canadian exports to Mexico. Adjusting for the increase in total trade, the external margin accounted for roughly 25 percent of the increased trade between Mexico and the United States, 40 percent of increased Mexican exports to Canada, and almost 100 percent of increased Canadian exports to Mexico.

Hillberry and McDaniel (2002), using an alternative measure, find evidence of smaller, but still significant, extensive margin growth for the United States following the implementation of NAFTA. Using the methodology of Hummels and Klenow (2005), they define a country's extensive margin as its share of world exports that occur in those product categories (measured HTS lines at the 10-digit level) in which a country exports. Other things equal, by this measure if a country concentrates its exports in a few product categories, it will have a lower extensive margin. Hillberry and McDaniel estimate that Mexican exports to the US grew by $\$ 86$ billion between 1993 and 2001, of which 12.5\% is attributable to greater extensive margin trade. Correspondingly, Mexican imports from the US grew by \$44 billion, of which 9.7 percent occurred at the extensive margin. Their lower magnitude estimates in comparison to Kehoe and Ruhl can be attributed to their different metric: Hillberry and McDaniel define a product category as traded even if actual exports, though positive, are virtually insignificant. In addition, they focus on the effects of NAFTA per se and not of trade liberalization undertaken by Mexico in earlier years.

Evidence regarding quantities for EMU is more limited. But there are good theoretical reasons and prior empirical evidence for expecting the adoption of a single currency to lead to increased trade among the members of a currency union (see Rose, 2000). While the data limitations are evident, there is already some evidence that EMU has boosted intra-euro area trade since 1999 (HM Treasury, 2003). EMU-specific calculations based on a structural model incorporating multilateral resistance suggest an increase in trade as high as 40 to 60 per cent. Other studies, e.g. Bun and Klassen (2002), yield smaller, though still, significant effects.

\footnotetext{
${ }^{7}$ This approach towards determining whether a particular set of goods are not traded assumes that the cutoff depends on the relative importance of these goods in a country's trade (e.g. 10 percent of total export value) rather than on whether their yearly value of trade falls below a fixed dollar-value cutoff (e.g. \$500, 000).
} 
Is there any connection between the quantity evidence and price evidence presented above? Specifically, is there any association between the observations that the extensive margin has increased and price dispersion has risen within Europe since the adoption of the euro? We present suggestive evidence that there is, through a simple regression of the change in price dispersion on the change in the extensive trade margin across individual country pairs. The price dispersion figures are constructed as above; the extensive trade margin figures are calculated from OECD data on International Trade by Commodity Statistics (ITCS), disaggregated at the 4 digit SITC product level. (We measure price dispersion changes and the extensive margin over the period 1998-2002 because of the absence of bilateral product-disaggregated trade data for most countries beyond 2002.) The results are reported in Table 3. A bivariate regression (in col. 1) indicates a positive, though insignificant relation. Controlling for differences between core and peripheral trading relationships yields more interesting results (see col. 2). The coefficient of the extensive margin variables, reflecting the effect for core-peripheral country pairs, is positive and significant at better than $5 \%$. For core-core country pairs the coefficient is even more positive. For peripheral pairs the effect is weaker. This suggests that the entry of new goods since 1998 is associated with an increase in price dispersion.

These results point out the need for a theoretical framework to understand trade liberalization that permits entry of new goods into the export market. We present one approach doing so in the following section. Alternatives have been proposed by Kehoe and Ruhl (2002), Ghironi and Melitz (2004), as well as others. But in addition, we propose a model that tries to account for the puzzling price evidence. Given the clear role for the extensive margin in explaining the quantity observations, our model will also consider how such an extensive margin can coincide with and even facilitate price divergence.

\section{Model Specification}

In this section we formulate an open economy macro model that specifies real trade frictions in the form of both per unit (iceberg) trade costs as well as a fixed cost of international trade. The model consists of two countries, home and foreign, in which each country's output consists of a distinct continuum of differentiated goods, denoted by labels $H$ and $F$, respectively. Each country's goods are indexed on the unit interval and are produced by monopolistically competitive firms using labor as the sole input in a linear (constant returns to scale) technology.

In principle, any good can be exported but there are variable costs $\tau$ and fixed costs of exporting $f_{X}$ for any good, which are borne by the exporting firm. Consequently, an endogenously determined fraction will be nontraded in equilibrium. Nontraded goods are labeled $N$ and traded goods $T$. Home and foreign agents consume CES aggregates of their own domestic goods and the other country's traded (export) goods. Quantities and prevailing prices for the goods varieties consumed in the foreign country are denoted by * (Below we generally present 
consumption and price expressions for the home country only; the corresponding expressions for the foreign country are analogous.)

There are several key assumptions in our framework. First, each country specializes in a range of goods that are unique to that country (albeit goods from different countries are substitutes) and that the continua of goods produced are exogenously given. ${ }^{8}$ Thus, in focusing on tradability, we abstract from possible new entrants into domestic production. Second, we aggregate consumption only over the mass of goods that are actually available to consumers; this mass may change over time as the number of imported tradable goods varies. In order to facilitate the construction of CES aggregates this necessitates assuming that elasticity between individual varieties of domestic and foreign goods are the same. This precludes the possibility of separate elasticities between home and foreign goods, and between traded and nontraded goods, which have often proven useful in open macro models. Third, we follow the tradition of standard open economy macro models by defining consumption aggregates as (weighted) averages of the consumptions of individual varieties, implying that consumption is invariant to the entry of new varieties. "This rules out the "love of variety" effect characteristic of Dixit-Stiglitz specifications which are popular in models of international trade and imply that utility rises with the number of varieties consumed. ${ }^{10}$ The implications of having "love of variety" or not are absent from open economy macro models, where the mass of firms is assumed constant, the number of available varieties never changes, and hence the baskets of goods consumed are fixed. ${ }^{11}$ Fourth, we permit productivity and iceberg transport costs to vary heterogeneously across goods varieties. As will be seen below, this gives our model flexibility necessary to explain the price and quantity puzzles of international economic integration trade liberalization discussed in Section II.

\section{A. Consumption}

The continuum of goods produced in each country is indexed by $i$ on the interval $[0,1]$. Let $n$ denote the (endogenous) share of these goods in the home country that are nontraded, where goods are ordered such that $i \in[0, n]$ are nontraded and $i \in[n, 1]$ are traded. (Analogously for the foreign country, where $n^{*}$ represents the share of foreign nontradeds.) Residents consume a basket of locally-produced goods and tradable goods imported from the other country.

\footnotetext{
${ }^{8}$ A different approach is to allow a common set of goods to be potentially produced in all countries, and then have only the lowest-cost supplier actually export the good to each market.

${ }^{9}$ The love of variety effect also implies that the aggregate price index falls with new varieties. This implies that the real exchange rate may move in the "wrong" direction (i.e. depreciate) if productivity gains generate entry, contrary to the prediction of the Balassa-Samuelson theory. The average price index that corresponds to our consumption index does not display this property.

${ }^{10}$ Kehoe (2003) points out that trade models with a love of variety specification and large home bias weights counterfactually predict that, in response to trade liberalization, the largest increases in trade should occur in sectors in which there already is significant trade.

${ }^{11}$ Benassy (1996) formulates a general specification with a parameter that nests "no love of variety" and "Dixit-Stiglitz love” as special cases.
} 
Consequently, the total mass of varieties of goods available for consumption in the home country is the sum of the mass of domestic varieties and of the goods exported by the foreign country, i.e. $1+\left(1-n^{*}\right)=2-n^{*}$.

Accordingly, aggregate consumption $(C$ ) can be defined as a CES aggregate of consumption of the home country's own goods $\left(C_{H}\right)$ and imports of the foreign country's traded (export) goods $\left(C_{F T}\right)$ :

$$
C=\left(\left(\theta\left[n^{*}\right]\right)^{\frac{1}{\phi}}\left(C_{H}\right)^{\frac{\phi-1}{\phi}}+\left(1-\theta\left[n^{*}\right]\right)^{\frac{1}{\phi}}\left(C_{F T}\right)^{\frac{\phi-1}{\phi}}\right)^{\frac{\phi}{\phi-1}}
$$

where $\phi>1$ is the elasticity of substitution between home and foreign goods, and $\theta\left[n^{*}\right]$ is the own-goods bias coefficient that depends endogenously on the number of imported varieties (see the appendix for the derivation):

$$
\theta\left[n^{*}\right] \equiv \frac{1}{2-n^{*}}, \quad 1-\theta\left[n^{*}\right] \equiv \frac{1-n^{*}}{2-n^{*}}, \quad 0 \leq \theta\left[n^{*}\right] \leq 1
$$

Consumption of the home country's own-good is in turn defined as a CES consumption index of its nontraded $\left(C_{H N}\right)$ and traded own goods $\left(C_{H T}\right)$ :

$$
\left(C_{H}\right)^{\frac{\phi-1}{\phi}}=\int_{0}^{n}\left(c_{H i}\right)^{\frac{\phi-1}{\phi}}+\int_{n}^{1}\left(c_{H i}\right)^{\frac{\phi-1}{\phi}} d i=\left(\frac{C_{H N}}{n}\right)^{\frac{\phi-1}{\phi}}+(1-n)\left(\frac{C_{H T}}{1-n}\right)^{\frac{\phi-1}{\phi}}
$$

where $C_{H N} \equiv\left[\left(\frac{1}{n}\right)^{\frac{1}{\phi}} \int_{0}^{n}\left(c_{H i}\right)^{\frac{\phi-1}{\phi}} d i\right]^{\frac{\phi}{\phi-1}}, \quad C_{H T} \equiv\left[\left(\frac{1}{1-n}\right)^{\frac{1}{\phi}} \int_{n}^{1}\left(C_{H i}\right)^{\frac{\phi-1}{\phi}} d i\right]^{\frac{\phi}{\phi-1}}$

and lower cases are used to denote consumption of individual varieties $i$ of each differentiated good. Again note that the elasticity of substitution among individual varieties of the home good and the foreign good is also assumed equal to $\phi .{ }^{12}$ At home, the $H N$ goods occupy $[0, n]$ and the $H T$ goods $[n, 1]$. (Correspondingly, abroad the FN goods occupy $\left[0, n^{*}\right]$ and the FT goods $\left[n^{*}, 1\right]$.)

Analogously, the consumption index of the foreign good imported by domestic agents $C_{F T}$ is defined as

$$
C_{F T} \equiv\left[\left(\frac{1}{1-n^{*}}\right)^{\frac{1}{\phi}} \int_{n^{*}}^{1}\left(c_{F i}\right)^{\frac{\phi-1}{\phi}} d i\right]^{\frac{\phi}{\phi-1}}
$$

\section{B. $\quad$ Prices and Relative Demands}

Price indexes are defined as usual for each category of goods, in correspondence to the consumption indices above:

\footnotetext{
12 That is, $c_{H i} / c_{H j}=\left(p_{H i} / p_{H j}\right)^{-\phi}, c_{F i}^{*} / c_{F j}^{*}=\left(p_{F i}^{*} / p_{F j}^{*}\right)^{-\phi}$ for any two goods $i$ and $j$.
} 


$$
P=\left(\theta\left[n^{*}\right]\left(P_{H}\right)^{1-\phi}+\left(1-\theta\left[n^{*}\right]\right)\left(P_{F T}\right)^{1-\phi}\right)^{\frac{1}{1-\phi}}
$$

where $P_{H}^{1-\phi}=\int_{0}^{n}\left(p_{H i}\right)^{1-\phi} d i+\int_{n}^{1}\left(p_{H i}\right)^{1-\phi} d i=n\left(P_{H N}\right)^{1-\phi}+(1-n)\left(P_{H T}\right)^{1-\phi}$

$$
\begin{aligned}
P_{H N} & \equiv\left(\left(\frac{1}{n}\right) \int_{0}^{n} p_{H i}^{1-\phi} d i\right)^{\frac{1}{1-\phi}}, \quad P_{H T} \equiv\left(\left(\frac{1}{1-n}\right) \int_{n}^{1} p_{H i}^{1-\phi} d i\right)^{\frac{1}{1-\phi}} \\
P_{F T} & \equiv\left(\left(\frac{1}{1-n^{*}}\right) \int_{n^{*}}^{1} p_{F i}^{1-\phi} d i\right)^{\frac{1}{1-\phi}}
\end{aligned}
$$

where $P$ is the aggregate domestic country price level, $P_{H}$ is the price index of all home goods, $P_{H N}$ is the price index of nontraded home goods, $P_{H T}$ is the price index of traded home goods, and $P_{F T}$ is the price (to domestic residents) of imported foreign goods.

Note that the consumption and price indices imply the following relative demand functions for domestic residents: ${ }^{13}$

$$
\begin{array}{ll}
C_{H} / C=\left(\theta\left[n^{*}\right]\right)\left(P_{H} / P\right)^{-\phi}, & C_{F T} / C=\left(1-\theta\left[n^{*}\right]\right)\left(P_{F T} / P\right)^{-\phi} \\
C_{H N} / C_{H}=n\left(P_{H N} / P_{H}\right)^{-\phi}, & C_{H T} / C_{H}=(1-n)\left(P_{H T} / P_{H}\right)^{-\phi}
\end{array}
$$

and analogously for foreign residents.

\section{Production and Productivity}

The production sector in each country consists of constant-returns-to-scale technologies for the output of each differentiated good:

$$
y_{H i}=A_{i} l_{H i},
$$

where $y_{H i}$ represents the level of home output, $l_{H i}$ denote workers employed in production, and $A_{i}$ is the home productivity coefficient for each individual good $i$. We employ the usual assumption that labor is mobile across sectors within each economy, but immobile across countries.

Profit maximization under monopolistic competition implies pricing is determined by the standard cost markup rule. For domestic sales of all home goods, either traded or nontraded goods:

$$
p_{H i}=\frac{\phi}{\phi-1} \frac{W}{A_{i}}, i \in[0,1],
$$

where $W$ denotes the home wage rate, and $\phi /(1-\phi)$ is the markup factor. For export sales of traded goods,

\footnotetext{
${ }^{13}$ Also note that the CES specification implies for individual goods variety $i$ $c_{H i} / C_{H}=\left(p_{H i} / P_{H}\right)^{-\phi}, c_{H i} / C_{H T}=(1-n)^{-1}\left(p_{H i} / P_{H T}\right)^{-\phi}$, and $c_{F i} / C_{F T}=\left(1-n^{*}\right)^{-1}\left(p_{F i} / P_{F T}\right)^{-\phi}$.
} 


$$
p_{H i}^{*}=\frac{\phi}{\phi-1} \frac{W}{A_{i}} \frac{1}{1-\tau_{i}}, \quad i \in[n, 1], \quad p_{F i}=\frac{\phi}{\phi-1} \frac{W}{A_{i}} \frac{1}{1-\tau_{i}^{*}}, \quad i \in\left[n^{*}, 1\right]
$$

where $\tau_{i}\left(0<1-\tau_{i}<1\right)$ is the fraction of each good $i$ lost during shipment and it is assumed that consumers fully absorb these iceberg costs of shipping. ${ }^{14}$ Thus for each traded good the foreign sales price exceeds the domestic price by the proportion $1 /\left(1-\tau_{i}\right)>1$ :

$$
p_{H i}^{*}=p_{H i} \frac{1}{1-\tau_{i}}, \quad p_{F i}=p_{F i}^{*} \frac{1}{1-\tau_{i}^{*}}
$$

Note that, in the absence of transport costs, sales prices are equalized across markets for each $\operatorname{good} i$, i.e. $p_{H i}=p_{H i}^{*}, \quad p_{F i}=p_{F i}^{*}$.

One important feature of the model is the distribution of productivities across each country. Firms in the domestic country have a distribution of productivity levels given by $F\left[A_{i}\right]$. Among these firms, $n=1-F\left[A_{n}\right]$ are nontraders and $1-n=F\left[A_{n}\right]$ are exporters.

We define special weighted productivity averages for home goods $\tilde{A}$, nontraded home goods $\tilde{A}_{\mathrm{N}}$, and traded home goods $\tilde{A}_{T}:{ }^{15}$

$$
\begin{aligned}
& (\tilde{A})^{\phi-1} \equiv \int_{0}^{1} A_{i}^{\phi-1} d i, \\
& \left(\tilde{A}_{N}[n]\right)^{\phi-1} \equiv \frac{1}{n} \int_{0}^{n}\left(A_{i}\right)^{\phi-1} d i, \\
& \left(\tilde{A}_{T}[n]\right)^{\phi-1} \equiv\left(\frac{1}{1-n}\right) \int_{n}^{1} A_{i}^{\phi-1} d i .
\end{aligned}
$$

The foreign productivity averages are analogous.

If goods are ordered with increasing productivity, then $\partial \tilde{A}_{T} / \partial n>0, \partial \tilde{A}_{N} / \partial n<0$, i.e. average productivity rises (falls) in the traded sector (nontraded) sector with increasing $n$. Intuitively, as the share of nontraded goods in the economy rises, goods at the low productivity end of the traded goods sector become nontraded, and the average level of productivity of all remaining traded goods rises. ${ }^{16}$

Transport costs may also vary heterogeneously across firms. We define the "effective" productivity of home good exports as $A_{i}\left(1-\tau_{i}\right)$, i.e. productivity adjusted by the transport costs of goods exported abroad, since higher $\tau$ effectively lowers the productivity of these goods relative to the same goods sold domestically.

\footnotetext{
${ }^{14}$ For example, if $\tau_{i}=0.5$, then $50 \%$ of good $i$ is lost in shipment and the firm doubles the price of the good that reaches the foreign market.

${ }^{15}$ As pointed out by Melitz (2003), weighting by the elasticity parameter $\phi$, makes the weights proportional to the relative output shares of firms.

${ }^{16}$ Note $(\tilde{A})^{\phi-1}=n\left(\tilde{A}_{N}[n]\right)^{\phi-1}+(1-n)\left(\tilde{A}_{T}[n]\right)^{\phi-1}$.
} 
We define the average effective productivity of home exports $\tilde{A}_{(1-\tau) T}$ as

$$
\left(\tilde{A}_{(1-\tau) T}[n]\right)^{\phi-1} \equiv\left(\frac{1}{1-n}\right) \int_{n}^{1}\left(\left(1-\tau_{i}\right) A_{i}\right)^{\phi-1} d i
$$

where the " $T$ " in the subscript indicates that these averages are computed over the range of goods that are traded. It is straightforward to express the price index for nontraded and traded home goods in terms of these productivity averages by using (14) to substitute for $p_{H i}$ in (8) and (9):

$$
P_{H N}=\frac{\phi}{\phi-1}\left(\frac{W}{\tilde{A}_{N}[n]}\right), \quad P_{H T}=\left(\frac{\phi}{\phi-1}\right) \frac{W}{\tilde{A}_{T}[n]}
$$

with (7) implying

$$
P_{H}=\frac{\phi}{\phi-1} \frac{W}{\tilde{A}}
$$

Correspondingly, the price of home goods exported to foreign residents is

$$
P_{H T}^{*}=\left(\frac{\phi}{\phi-1}\right) \frac{W}{\tilde{A}_{(1-\tau) T}[n]}
$$

Equations (21) and (22) express the prices of nontraded and traded goods as functions of the wage rate $W$, the relevant productivity averages, and the share of nontraded goods $n$. Observe that these prices are increasing in the wage rate and decreasing in average productivity. Since $\tilde{A}$ is independent of $n$, the nontraded vs. traded goods composition of the economy affects $P_{H}$ only through its effect on the average wage level in the economy. In the absence of any transport costs at all, all goods are traded $(n=0)$, implying $\tilde{A}=\tilde{A}_{(1-\tau) T}=\tilde{A}_{T}$, and prices of all goods are equalized: $P_{H}=P_{H T}=P_{H T}^{*}$. Keep in mind that $n$ (and $n^{*}$ ) is itself an endogenous variable that will be solved as part of the general equilibrium system

\section{Marginal Trading Condition}

The additional profit to a home firm $i$ of exporting to the foreign market may be written:

$$
\pi_{H i}^{*}=\left(p_{H i}^{*}-\frac{W}{A_{i}} \frac{1}{1-\tau_{i}}\right) c_{H i}^{*}-W f_{X}
$$

where the operating profits are defined as the export price minus marginal cost, times the volume of sales to foreign residents. We follow Ghironi and Melitz (2004) in assuming that firms employ domestic workers to cover the fixed costs. With $f_{X}$ measured in units of effective domestic labor and $W$ as the wage rate of this labor, labor costs are expressed as $W f_{X} \cdot{ }^{17}$ If this additional profit is

\footnotetext{
${ }^{17}$ In general, the effective labor employed to cover the fixed costs should depend on the productivity of the labor employed and the wage rate should be scaled by this level of productivity, which we can
} 
positive, the firm will choose to export; if negative, the firm will not. This provides the condition that pins down the index of the marginal trading firm and hence the share of nontraded goods. For firm index $i=n$ the profit from exporting is exactly zero, so

$$
\left(p_{H n}^{*}-\frac{W}{A_{n}} \frac{1}{1-\tau_{n}}\right) c_{H n}^{*}=W f_{X}
$$

\section{E. Closing and Solving the Model}

Labor market equilibrium in each country requires that labor employed in production of nontraded and traded home goods plus labor employed to cover the fixed costs of exporting equal the (exogenous) domestic labor supply $L_{H}$. In the appendix we show that this condition implies the following relation for the home country ${ }^{18}$ :

$$
W L_{H}-(1-n) f_{X} W=\left(\frac{\phi-1}{\phi}\right)\left[P_{H} C_{H}+P_{H T}^{*} C_{H T}^{*}\right]
$$

i.e. the domestic wage bill—net of wages paid for workers employed in covering fixed costs, $W(1-n) f_{X}$-is proportional to the value of home goods consumed domestically or exported, with the proportionality constant equal to 1 minus the profit rate $1 / \phi$.

We close the model with the balanced trade condition that the value of exports equals the value of imports

$$
P_{H T}^{*} C_{H T}^{*}=P_{F T} C_{F T}
$$

and the normalization condition

$$
P^{*}=1 \text {. }
$$

Equilibrium determines the 24 variables $C, C_{H}, C_{H N}, C_{H T}, C_{F T}, P, P_{H}, P_{H N}, P_{H T}, P_{F T}, W$, and $n$ and their foreign counterparts (denoted by *) by solving the system of 24 equations (1)-(7), (21)-(22), (25b), and (26) plus their foreign counterparts, together with (27) and (28). In words, production markups link prices to wages. Standard CES demand conditions link prices to consumption quantities and, thence, via technology, to derived labor demand. Market clearing (including balanced trade) and the numéraire choice yield a solution conditional on given nontraded shares $n$ and $n^{*}$. The marginal trading conditions render the producers of the borderline traded-nontraded good indifferent between home and foreign sales, and, given the costs of shipping, this pins down $n$ and $n^{*}$ in equilibrium and completes the solution.

denote $A_{f x} A_{f x}$ may be assumed exogenously given or related to productivity elsewhere in the economy, e.g. $\tilde{A}$, the average aggregate productivity level. We abstract from this issue by normalizing $A_{f x}$ to 1 . ${ }^{18}$ When all home goods are nontraded, i.e. $n=1$, then no labor is employed to cover fixed costs of exporting. 


\section{Analytical Results and Discussion}

In this section we discuss some of the general insights of our framework for economic integration. In particular, we focus on illustrating the differential effects of changes in iceberg and fixed costs on cross-country price differences and trade flows. Simulations in the following section will complete the analysis and understanding of the model. ${ }^{19}$

\section{A. Preliminaries: Decomposition into Homogenous and Heterogeneous Components.}

Our model potentially permits heterogeneity in two different dimensions: in terms of productivity and in iceberg transport costs. In the following discussion it will prove useful to decompose productivity and iceberg transport costs for good $i$ into homogenous $(\alpha)$ and heterogeneous ( $\beta$ ) components. We will address two (polar) cases: (i) heterogeneity in productivity only, and (ii) heterogeneity in iceberg costs only (we report only home country expressions; the foreign country counterparts are analogous):

In the case of heterogeneity in productivity only, we may write the distributions as

$$
\begin{array}{lll}
A_{i}=\alpha_{A} \beta_{A}[i], & i \in[0,1], & 0<\alpha_{A}, \beta_{A} \\
1-\tau_{i}=\alpha_{1-\tau}, & i \in[0,1], & 0 \leq \alpha_{1-\tau} \leq 1
\end{array}
$$

implying effective productivity can be expressed as

$$
A_{i}\left(1-\tau_{i}\right)=\left(\alpha_{A} \beta_{A}[i]\right) \alpha_{1-\tau} .
$$

Changes in $\alpha_{A}, \alpha_{1-\tau}$ represent balanced changes in productivity and transport costs affecting all goods equally. Note a rise in $\alpha_{1-\tau}$ implies a decline in iceberg costs. It follows that the productivity averages can be expressed (with the foreign counterparts defined analogously) as:

$$
\begin{aligned}
& \tilde{A}=\alpha_{A}\left[\int_{0}^{1}\left(\beta_{A}[i]\right)^{\phi-1} d i\right]^{\frac{1}{\phi-1}} \equiv \alpha_{A}\left(\widetilde{\beta}_{A}\right) \\
& \tilde{A}_{T}[n]=\alpha_{A}\left[\frac{1}{1-n} \int_{n}^{1}\left(\beta_{A}[i]\right)^{\phi-1} d i\right]^{\frac{1}{\phi-1}} \equiv \alpha_{A}\left(\widetilde{\beta}_{A T}[n]\right) \\
& \tilde{A}_{(1-\tau) T}[n]=\alpha_{A} \alpha_{1-\tau}\left[\frac{1}{1-n} \int_{n}^{1}\left(\beta_{A}[i]\right)^{\phi-1} d i\right]^{\frac{1}{\phi-1}} \equiv \alpha_{A} \alpha_{1-\tau}\left(\widetilde{\beta}_{A T}[n]\right)
\end{aligned}
$$

\footnotetext{
${ }^{19}$ Bergin, Glick, and Taylor (2004) formulate a similar model without iceberg costs in order to investigate the effects of productivity growth on the real exchange rate and the range of goods traded. Their framework provides a more generalized approach to the Balassa-Samuelson hypothesis and its relationship to long-run growth.
} 
Assuming that goods are ordered with increasing productivity i.e. $\partial \beta_{A} / \partial i>0$, then $\partial \widetilde{\beta}_{A T} / \partial n>0$, $\partial \tilde{A}_{T} / \partial n>0$. That is, average productivity in the traded sector rises as $n$ increases and the traded goods share declines.

In the alternative case of heterogeneity in transport costs only, we write the distributions

$$
\begin{array}{lll}
A_{i}=\alpha_{A}, & i \in[0,1], & 0<\alpha_{A} \\
1-\tau_{i}=\alpha_{1-\tau} \beta_{1-\tau}[i], & i \in[0,1], & 0 \leq \alpha_{1-\tau}, \beta_{1-\tau} \leq 1
\end{array}
$$

implying effective productivity can be expressed as

$$
A_{i}\left(1-\tau_{i}\right)=\alpha_{A}\left(\alpha_{1-\tau} \beta_{1-\tau}[i]\right) .
$$

The corresponding averages are

$$
\begin{aligned}
& \tilde{A}=\alpha_{A} \\
& \tilde{A}_{T}[n]=\alpha_{A} \\
& \tilde{A}_{(1-\tau) T}[n]=\alpha_{A} \alpha_{1-\tau}\left[\frac{1}{1-n} \int_{n}^{1}\left(\beta_{1-\tau}[i]\right)^{\phi-1} d i\right]^{\frac{1}{\phi-1}} \equiv \alpha_{A} \alpha_{1-\tau}\left(\tilde{\beta}_{(1-\tau) T}[n]\right)
\end{aligned}
$$

Assuming that goods are ordered with decreasing iceberg costs, i.e. $\partial \beta_{1-\tau} / \partial \mathrm{i}>0$, then $\partial \widetilde{\beta}_{(1-\tau) T} / \partial n>0, \partial \tilde{A}_{(1-\tau) T} / \partial n>0$, i.e., average heterogeneity and transportability rise in the traded sector with increasing $n$.

\section{B. Tradability}

One immediate conclusion is the equivalence, in terms of their effects on tradability, of the trade cost heterogeneity that we advocate and the heterogeneity in productivity that has been the focus of other recent papers. This may be seen by considering the trading condition for firm $i$ (25a), substituting out all firm-specific endogenous variables and making some additional simplifying substitutions. We use the price setting conditions (15) and (24) to substitute for $p_{H i}^{*}$ and $P_{H T}^{*}$ and the relative demand condition $c_{H i}^{*} / C_{H T}^{*}=(1-n)^{-1}\left(p_{H i}^{*} / P_{H T}^{*}\right)^{-\phi}$ for $c_{H i}^{*}$ to find:

$$
\left(A_{i}\left(1-\tau_{i}\right)\right)^{\phi}\left(\frac{\left(\tilde{A}_{(1-\tau) T}[n]\right)^{-\phi} C_{H T}^{*}}{(\phi-1)(1-n)}\right)=f_{X} .
$$

In this equation, the good-specific trade cost term and that for technology appear only as a product, $A_{i}\left(1-\tau_{i}\right)$, so it is only the net effect of the two terms that matters for the relative ranking of varieties in terms of their tradability. For example, even if a good $i$ is more costly to trade than a good $j, \tau_{i}>\tau_{j}$, good $i$ nevertheless can be more tradable if it has a sufficiently high level of productivity so that $A_{i}\left(1-\tau_{i}\right)>A_{j}\left(1-\tau_{j}\right)$. Conversely, there also may be some highly productive goods that nevertheless will probably never be traded, because they have particularly 
high good-specific transport costs. Goods can in principle be ranked in terms of tradability using this composite metric.

We next obtain some insight into the extensive margin of trade by considering the trading condition for the marginal good (25b). Using the price setting condition (15) for $p_{H n}^{*}$ and noting that the relative demand condition $c_{H i}^{*} / C_{H T}^{*}=(1-n)^{-1}\left(p_{H i}^{*} / P_{H T}^{*}\right)^{-\phi}$ holds for all goods $i$ in the range $[n, 1]$ :

$$
\left\{\frac{1}{\phi-1}\left(\frac{1}{A_{n}\left(1-\tau_{n}\right)}\right)\right\}\left\{\left(\frac{p_{H n}^{*}}{P_{H T}^{*}}\right)^{-\phi} \frac{C_{H T}^{*}}{1-n}\right\}=f_{X} .
$$

In this form, we can infer that the nth firm's variable profits depend on two factors: (1) per unit export profits - the term in the first set of curlicue brackets on the LHS, expressed as a proportion 1/( $\phi-1)$ of marginal costs, and (ii) the quantity of exports sold - the term in the second set of curlicue brackets. The latter, in turn, can be decomposed into the relative price effect on demand for the $n$th firm's exports, $\left(p_{H n}^{*} / P_{H T}^{*}\right)^{-\phi}$, and its share of the aggregate level of exports sold abroad, $C_{H T}^{*} /(1-n)$.

When variable exports profits exceed the fixed costs of exporting - either because per unit profits or the volume of exports are high - goods with effective productivity lower than that of the initial $n$th good will become traded (since even though $A_{i}\left(1-\tau_{i}\right)<A_{n}\left(1-\tau_{n}\right)$ for these goods, it has become profitable to export them). The resulting decline in $n$ and rise in the share of tradable goods 1- $n$ raises the marginal cost and price of the marginally traded good and reduces its share of aggregate exports. These effects cause both per unit profits and the export volume to fall. In equilibrium, profits are reduced to just covering the fixed costs of the $n$th good entering into the foreign export market.

Equation (32) is useful for understanding the effect of trade policies on the entry of new goods into trade, and how this depends on the type of trade policy. We consider cuts in iceberg costs and fixed costs in turn.

Consider first a balanced cut in per unit (iceberg) costs, i.e. a rise in $\alpha_{1-\tau}, \alpha_{1-\tau}^{*}$. Equation (32) suggests a number of offsetting effects that could make the effect on new entry of exporters small. First, under monopolistic competition, firms pass on tariff changes into the sales price charged to foreign consumers (see expression (15)); consequently the lower export price implies lower per unit export profits for the $n$th firm. Second, because the cut in tariffs affects all traded goods equally, the relative price of the $n$th firm's exports $\left(p_{H n}^{*} / P_{H T}^{*}\right)$ is unaffected..$^{20}$ Lastly, it is

\footnotetext{
${ }^{20}$ These effects can be seen more clearly by noting that (29)-(31) imply (32) may be expressed as $\left\{\frac{1}{\phi-1}\left(\frac{1}{\alpha_{A} \alpha_{1-\tau} \beta_{1-\tau}[n]}\right)\right\}\left\{\left(\frac{\widetilde{\beta}_{(1-\tau) T}[n]}{\beta_{1-\tau}[n]}\right)^{-\phi}\left(\frac{C_{H T}^{*}}{1-n}\right)\right\}=f_{X}$ with productivity heterogeneity only, and
} 
only though an increase in demand for aggregate exports $C_{H T}^{*}$, i.e. an increase in trade at the intensive margin, that the $n$th firm may experience an overall increase in export profits. If aggregate exports increase sufficiently to raise variable profits above fixed costs, then new goods may become traded and trade will increase at the extensive margin (i.e. the equilibrium $n$ falls and the share of traded goods $1-n$ increases).

The increase in aggregate exports reflects increased trade at the intensive margin. The amount by which aggregate exports rise depends on the elasticity of demand for exports. Considering the foreign counterpart to equation (10)

$$
C_{H T}^{*}=(1-\theta[n])\left(P_{H T}^{*} / P^{*}\right)^{-\phi} C^{*}
$$

we see that a per unit cost cut induces firms to lower the relative price of tradables (i.e. $P_{H T}^{*} / P^{*}$ falls), which boosts foreign demand for home goods exported to the foreign market. It is apparent that the magnitude of increased demand for exports falls as the elasticity of demand declines. Consequently, the effect on the profits of the marginal trader and the incentive for new entrants is less as well. ${ }^{21}$ In fact, because of the negative effects of a cut in tariffs on per unit profits, we cannot rule out the possibility that this effect dominates any increase in export volume, implying profits of the marginal trader actually decline, leading him to exit the tradables market. Numerical simulations for a calibrated version of the model will show later that the net effect tends to be a rise in profits, implying some fall in $n$, and some increase in trade at the extensive margin.

Consider now the alternative policy, a decline in fixed costs $\left(f_{X}, f_{X}^{*}\right)$. Since fixed trade costs only enter into the marginal trading condition; they do not enter into the decision rules about price setting or how much to produce and sell. Hence, in the case of a fixed trade cost reduction, there is a direct effect raising the export profits of the marginal exporter, since variable profits will exceed the now lower fixed costs of exports. There is no effect on per unit profits - unlike the case of a tariff cut_or the relative price of the marginal exporter. The positive export profits for the marginal trader leads to an increase in trade at the extensive margin (i.e. decline in $n$ ) as it becomes profitable for new goods to enter the traded sector.

To summarize, a cut in fixed costs will work largely through the entry of new goods into the traded sector, implying greater trade at the extensive margin. In contrast, a cut in per-unit trade costs will tend to raise exports mostly through increasing the intensity of trade in

$\left\{\frac{1}{\phi-1}\left(\frac{1}{\alpha_{A} \alpha_{1-\tau} \beta_{A}[n]}\right)\right\}\left\{\left(\frac{\widetilde{\beta}_{A T}[n]}{\beta_{A}[n]}\right)^{-\phi}\left(\frac{C_{H T}^{*}}{1-n}\right)\right\}=f_{X}$ with transport cost heterogeneity only.

${ }^{21}$ We conjecture that this is most likely to occur as one approaches the limiting case of Cobb-Douglas preferences between home and foreign goods, where elasticity for imports is unity. In our current specification with endogenous home bias weights, however, we are precluded from considering this case because of the constraint that the elasticity between home and foreign goods be the same as that among individual varieties of home (and foreign ) goods, which must exceed unity with CES preferences. With exogenous home bias weights, this constraint can be dropped and the different elasticities can be posited. 
previously traded goods; i.e. firms already trading, will export more. The extensive effect on trade is dampened in this case because lower marginal costs lead to proportionately lower prices, and hence lower per unit profits from exporting. This limits the extent to which new firms find it profitable to engage in exporting.

\section{Law of One Price and Price Divergence}

We next examine the circumstances under which deviations from the law of one price may emerge in our model. At the level of individual goods $i$, it is immediately apparent that monopolistic pricing — see expressions (15) and (16)—implies the export price exceeds the domestic price of good $i$ by a wedge associated with transport costs:

$$
\frac{p_{H i}^{*}}{p_{H i}}=\frac{1}{1-\tau_{i}}=\frac{1}{\alpha_{1-\tau} \beta_{1-\tau}[i]}>1, \quad i \in[n, 1] .
$$

With homogeneous trade costs the degree of price divergence is constant across sectors. However, if $\beta_{1-\tau}[i]$ and $1-\tau_{i}$ vary with $i$, the degree of price divergence varies with $i$ as well. Thus variations across sectors in the degree of LOP deviations depend on the presence of heterogeneous transport costs; with monopolistic pricing, heterogeneous productivity is not sufficient.

We will summarize results for price dispersion in terms of cross-border deviations in average tradable prices. Expressions (22) and (24) together with (19) and (20) imply

$$
\frac{P_{H T}^{*}}{P_{H T}}=\frac{\tilde{A}_{T}[n]}{\tilde{A}_{(1-\tau) T}[n]}>1
$$

since the presence of transport costs implies $\tilde{A}_{T}>\tilde{A}_{(1-\tau) T}$, i.e. the average effective productivity of tradable goods (i.e., including transport costs) is less than the average productivity of tradable goods. Consequently, the average price to foreign residents of exported home goods is higher than the average domestic price of the same goods at home. This relative price ratio roughly corresponds to the measure of price dispersion used in our empirical results reported in Table $1 .^{22}$

How does economic integration affect price deviations? The answer depends on the form of liberalization - iceberg transport costs or fixed trade costs - and on whether heterogeneity exits in the form of productivity or iceberg costs. We know from the previous section that both forms of liberalization induce some increase in trade at the extensive margin, i.e. decline in $n$, with this increase being greater in the case of a fixed trade cost reduction. As we shall see, the effect on trade liberalization depends on how the endogenous change in the degree of tradability interacts with the nature of heterogeneity. We again consider the effects of cuts in iceberg costs and in fixed costs in turn, and this time we must also distinguish between alternative types of

\footnotetext{
${ }^{22}$ Our empirical measure of dispersion is constructed from mean squared errors with equal weights across goods. Our theoretical measure does not square price deviations and uses CES weights. But because all deviations are positive here by construction, squaring does not matter and the two measures of price dispersion are monotonically related.
} 
heterogeneity. The reader will find the results for the four cases discussed here summarized in Figure 2.

First, consider a decline in iceberg costs $\left(\alpha_{1-\tau}, \alpha_{1-\tau}^{*}\right.$ rise) under the assumption of productivity heterogeneity. In this case, (30a) and (31a) imply (33) reduces to

$$
\frac{P_{H T}^{*}}{P_{H T}}=\frac{1}{\alpha_{1-\tau}},
$$

indicating that deviations from LOP at the aggregate level depend only on the homogenous transport cost parameter $\alpha_{1-\tau}$, An increase in $\alpha_{1-\tau}$, i.e. balanced decrease in transport costs, implies a fall in $P_{H T}^{*} / P_{H T}$ and reduces the average deviation from LOP.

Next, consider how this policy changes under transport cost heterogeneity. Transport cost heterogeneity implies that (33) reduces to

$$
\frac{P_{H T}^{*}}{P_{H T}}=\frac{1}{\alpha_{1-\tau} \widetilde{\beta}_{(1-\tau) T}[n]},
$$

and deviations from LOP at the aggregate level depend on the relative heterogeneity of transport costs $\left(\widetilde{\beta}_{(1-\tau) T}\right)$ as well as on the homogeneous transport cost component $\left(\alpha_{1-\tau}\right)$. The direct effect of a homogenous cut in costs (i.e. increase in $\alpha_{1-\tau}$ ) is to reduce price divergence. But there is also a potentially offsetting effect to consider through the endogenous changes in tradability on the heterogeneous component of transport costs. Specifically, a decrease in $n$, implying an increase in the number of tradable varieties, implies that trade costs are averaged over goods with higher costs, i.e., lower $1-\tau_{i}$. The resulting fall in $\widetilde{\beta}_{(1-\tau) T}[n]$ (since $\partial \widetilde{\beta}_{(1-\tau) T}[n] / \partial n>0$ ) raises the degree of price divergence. Our simulation exercises (in Section V) reveal that the latter effect is dominated by the direct effect of the cut in costs, and price divergence falls on balance.

Now consider the type of policy that cuts fixed costs $\left(f_{X}, f_{X}^{*}\right.$ fall). Fixed costs do not affect deviations from LOP at the sector level, but they can affect deviations at aggregate level to the extent they affect $n$. In the case of productivity heterogeneity, the relation (34a) applies, and the degree of price divergence is unaffected by any change in fixed costs. Intuitively, given that price setting is determined by per unit costs and not fixed costs, a cut in fixed costs has no effect on export prices. Thus in this case there is no reason in this model to expect prices to converge as the economies become more integrated.

However, in the presence of transport cost heterogeneity, (34b) holds and deviations from LOP depend on the heterogeneity of transport costs $\left(\widetilde{\beta}_{(1-\tau) T}\right)$ as well homogeneous transport costs $\left(\alpha_{1-\tau}\right)$. In this case a decline in fixed costs that fosters decreased $n$ and increased tradability, reduces $\widetilde{\beta}_{(1-\tau) T}[n]$ and raises price disparity. In words, if the source of heterogeneity is in terms of iceberg costs, then the newly tradable goods systematically will be those goods with higher per unit costs. Given the lower fixed costs, it now becomes profitable to trade these goods, despite the higher per unit costs. Given that price setting responds to these costs, the newly 
traded goods will tend to have a greater price wedge between national markets, so that average price dispersion of all traded goods will increase.

To sum up, iceberg costs play an important role in explaining market segmentation as measured in terms of price deviations, because fixed costs have no impact on the pricing behavior of monopolistically competitive firms. Cuts in iceberg costs reduce price disparities across markets. Moreover, only heterogeneity in iceberg costs can explain heterogeneity of LOP deviations. In contrast, fixed trade costs reductions in the presence of transport cost heterogeneity has the potential to explain why price divergence may actually increase when account is taken of endogenous changes in the tradability of goods.

One can also use the model to trace the effects of policies on a third important variable, the total volume of trade. We find there are several offsetting effects which obscure analytical conclusions. So we instead present results for this variable in the numerical simulations below, and refer the reader interested in the analytical discussion to the appendix.

\section{The Possibility of Endogenous Markups}

In this section we briefly deal with another possible channel by which the extensive margin could affect price dispersion. It is convenient for the analysis above that the equilibrium conditions governing price setting are not direct functions of the number of firms. This is a result of following the convention in international macro modeling, where the market structure is monopolistic competition and preferences have a constant elasticity, together implying that prices are a constant markup over costs. However, one possible reason offered for price dispersion across European countries is that there is greater competition in some national markets than others, implying that trade may reduce price dispersion by increasing competition in markets where it was especially low.

Several theories posit reasons why the elasticity of substitution may not be constant, but instead be a positive function of the number of firms competing in a market. This property would be implied by the translog preferences of Feenstra (2002) and Bergin and Feenstra (2001), and the strategic behavior in Jaimovich (2004) and Atkeson and Burstein (2005). Although combining either of these features in a model with the heterogeneity emphasized here is prohibitive, we can infer the implications if we specify the elasticity of substitution between home goods to be a positive function of the mass of home firms in a given national market. In this case the elasticity faced by home exporters in the foreign market is a negative function of the share of nontraded goods: $\phi=\phi[1-n], \partial \phi / \partial n<0$. The elasticity for these home firms in the domestic market can be expressed as $\phi[1]>\phi[n]$ for $n<1$; hence the elasticity of substitution is greater at home than abroad. Working through the price setting conditions of the model, the condition characterizing price dispersion (33) is replaced by: 


$$
\frac{P_{H T}^{*}}{P_{H T}}=\frac{\left(\frac{\phi[n]}{\phi[n]-1}\right)}{\left(\frac{\phi[1]}{\phi[1]-1}\right)} \frac{\tilde{A}_{T}[n]}{\tilde{A}_{(1-\tau) T}[n]}>1
$$

since $\frac{\phi[n]}{\phi[n]-1}>\frac{\phi[1]}{\phi[1]-1}$ and $\tilde{A}_{T}[n]>\tilde{A}_{(1-\tau) T}[n]$. Because there are fewer home firms in the foreign market to compete with, the elasticity is lower and the markup higher, generating a new reason for price dispersion. Condition (34a) characterizing price dispersion under productivity heterogeneity becomes

$$
\frac{P_{H T}^{*}}{P_{H T}}=\left(\frac{1}{\alpha_{1-\tau}}\right)\left(\frac{\phi[n]}{\phi[n]-1}\right) /\left(\frac{\phi[1]}{\phi[1]-1}\right) .
$$

This indicates that a rise in trade at the extensive margin that lowers $n$ can now lower price dispersion (since $\partial \phi / \partial n<0$ ), whereas in the previous model it had no effect. Similarly, for the case of trade cost heterogeneity, condition (34b) becomes

$$
\frac{P_{H T}^{*}}{P_{H T}}=\left(\frac{1}{\alpha_{1-\tau} \tilde{\beta}_{(1-\tau) T}[n]}\right)\left(\frac{\phi[n]}{\phi[n]-1}\right) /\left(\frac{\phi[1]}{\phi[1]-1}\right) .
$$

New trade at the extensive margin now has offsetting effects: still raising average price dispersion though the average trade cost term $\left(\tilde{\beta}_{(1-\tau) T}[n]\right)$, but now also lowering price dispersion through changes in the markup.

So one certainly can posit a model where price-setting decisions are affected by policies cutting fixed costs, working though the extensive margin, and not just by policies cutting per-unit costs, as implied by our benchmark model. But this additional effect on prices would work in the wrong direction to explain the price observations noted at the beginning of this paper, working always to reduce price dispersion after new trade, not increase it. For this reason, we chose not to pursue this modeling path in this paper, instead developing a model in a new direction.

\section{Numerical Results}

\section{A. Calibrations}

In several of the cases discussed above, trade liberalization had ambiguous effects, due to the fact that they involved multiple effects, sometimes working in offsetting directions. In part to help resolve these ambiguities, we use numerical simulations below. 
Simulations calibrate the parameter $\phi$ at the value 6 . This parameter represents the elasticity between any two varieties, and is set to reflect a price markup over cost of 0.2 , which is a common value used in the literature (see Obstfeld and Rogoff, 2000). ${ }^{23}$

Simulations require that particular distributions be specified for the heterogeneous elements. Productivity will follow the distribution:

$$
A_{i}=\alpha_{A}(1+i)^{\beta_{A}}, \quad i \in[0,1], \quad 0<\alpha_{A}
$$

and iceberg costs follow the distribution

$$
1-\tau_{i}=\alpha_{1-\tau}(1+i)^{\beta_{1-\tau}}, i \in[0,1], \quad 0 \leq \alpha_{1-\tau}
$$

where $\alpha_{A}$ and $\alpha_{1-\tau}$ are scale parameters representing level effects common to all goods, while $\beta_{A}$ and $\beta_{1-\tau}$ are parameters indicating the degree of heterogeneity over firms along the continuum indexed by $i$.

\section{B. $\quad$ Per Unit Cost Reductions}

The first simulation will consider the case where the source of heterogeneity is productivity, with distribution parameters set at $\alpha_{A}=0.5, \beta_{A}=1$, and $\alpha_{1-\tau}=0.9, \beta_{1-\tau}=0$. This implies a constant per-unit trade cost near $10 \%$ for all firms, which could be interpreted as a tariff rate. Figure 3 illustrates the distributions for technology and iceberg costs over the continuum of home goods. The experiment will consider a symmetric rise in $\alpha_{1-\tau}$ of one percent for both countries, which lifts the $1-\tau_{i}$ line for all varieties. This could be viewed as a $10 \%$ scaled reduction in the tariff rate. To ensure a share of nontraded goods near fifty percent, the fixed cost $f_{X}$ is calibrated at 0.056 . The foreign country is exactly symmetric.

The results of this experiment are shown in Table 4, where column 1 reports initial values before the tariff reduction. The export share of less than one half indicates some degree of home bias in consumption, arising from the presence of trade costs that make imported goods more expensive than domestic goods. Column two reports the percentage change from steady state values after the tariff reduction. The finding in Section IV regarding clear convergence in relative prices is confirmed in the last line of the table. The ten percent reduction of per unit costs, which themselves are ten percent of goods' value, amount to a one percent reduction in per unit cost, which directly translates into an exactly $1 \%$ reduction in the price deviation of home traded goods across countries. The last column of the table shows percent changes from steady state if the share of nontraded goods is assumed to be exogenous at the steady state level. This column makes clear that this simple price convergence result does not depend upon entry of new firms into exporting.

\footnotetext{
${ }^{23}$ Note that this elasticity also doubles as the elasticity between home and foreign goods. Recent work suggests that this elasticity might be lower than 6 , but as discussed earlier in the paper, separating these two elasticities is difficult when the set of home goods exported is allowed to change endogenously.
} 
One ambiguity in the analytical solution is the degree of entry and increase in trade share. While the fall in export prices raises foreign demand for home exports, thereby increasing the profitability of paying the fixed cost of exporting, any new entrants will have systematically lower productivity and hence higher prices than the average among previous entrants. Line 1 of the table shows that there indeed is entry of new exporters, as the share of nontraded goods ( $n$ ) falls. Line 2 shows that this enhances the increase in trade volume, compared to the case where there was no entry shown in the last column. But line 3 shows that the contribution of this extensive margin shift is relatively modest, accounting for 20 percent of the increased trade.

Next, we explore the effects of assuming heterogeneity in terms of transport costs instead of productivities. Distribution parameters in this case are: $\alpha_{A}=1, \beta_{A}=0, \alpha_{1-\tau}=0.5$ and $\beta_{1-\tau}=1$. Figure 4 illustrates the distributions. Again consider an experiment where $\alpha_{1-\tau}$ rises one percent, representing a tariff cut that raises the $1-\tau_{i}$ line for all varieties.

The effects of the tariff cut on quantity variables under transport cost heterogeneity are qualitatively similar to those under productivity heterogeneity above (see Table 5). Once again there is entry at the extensive margin which enhances export volume; once again the contribution of the extensive margin is modest, here contributing $23 \%$ of the rise in trade. But the response of price dispersion differs from the case above, in that a $1 \%$ tariff reduction no longer translates into a full $1 \%$ reduction in price deviations. Now there is only a 0.75 percent point reduction, due to the fact that the new entrants systematically have higher iceberg costs than the average trader, thus putting upward pressure on the average. While this effect moderates the degree of price convergence, it does not dominate, and on net there is positive price convergence.

\section{Fixed Cost Reduction}

Consider next experiments that instead reduce the fixed cost of trade. The two cases will use the same pair of distributions graphed in previous section, and this will imply that the starting values for our variables in the tables below will be the same as those in the two tables above. The experiment will be a reduction in the term $f_{X}$ by $10 \%$.

First, compare fixed versus per-unit cost cuts for the case of technological heterogeneity. The most striking feature in Table 6 is that there is no price convergence, confirming the finding in the analytical results in the previous section. Simulations have more new things to say about quantities, since they present more ambiguities in the analytics. Comparing Table 6 to Table 4, we can confirm the conjecture that there should be much more entry into exporting. However, despite this greater extensive margin growth, the overall export share in GDP rises less. This is because as new firms enter the market, firms previously trading experience an actual decline in their share of the export market. This implies the intensive margin growth is smaller, so that the share of new trade due the extensive margin exceeds $100 \%$.

Under transport cost heterogeneity (see Table 7) the price implications are even more dramatic. Once again the extensive margin effect drives the rise in overall trade. As conjectured 
in the analytics, the new entrants systematically have a greater price wedge, and because the extensive margin dominates here, there is actual price divergence on average. This result confirms the analytical prediction, showing that the model can offer one potential explanation for why policies aimed at market integration may sometimes imply negative average price convergence.

\section{Concluding Arguments}

This paper suggests a new approach for thinking about international macroeconomic segmentation and integration. Empirical evidence suggests that price convergence and trade volume expansion, two common measures for goods market integration, need not coincide. Recent efforts to promote economic integration in Europe and in North America seem to have prompted significant increases in trade volume, much of it on the extensive margin. But there appears to be very little price convergence, and some evidence suggests price divergence for many traded goods.

We propose a model of economic integration that is more general in its implications, and which can explain a range of varied relationships between price and quantities. The model relied upon two distinctive features. First, as an alternative to heterogeneity in productivity, it allows for heterogeneity in terms of iceberg trade costs, where the reason some goods are not traded is that these goods tend to have higher costs of trade. This feature is motivated by recent empirical work in the trade literature (Hummels 1999, 2001; Anderson and van Wincoop, 2003) which emphasize that trade costs vary greatly across classes of goods and play an important role in trade decisions. The existence of heterogeneous trade costs implies that when goods market integration promotes new trade in the extensive margin, the new entrants systematically have higher per unit trade costs than average trading firms. Since it is per-unit trade costs that create price wedges between national markets, the new entrants into export markets put upward pressure on the average price wedge, possibly increasing price divergence.

The second model feature is the distinction between fixed costs and per unit costs of trade. If trade reform exclusively takes the form of lower tariffs paid on a per unit bases, this tends to lower the price wedge for all goods. However, if the reform takes the form of mainly a cut in the fixed costs of trade, then it has no effect on the price-setting of goods, and there is no effect on the price wedge between countries.

In different combinations, these features permit a range of degrees of price convergence. First, a tariff cut without trade-cost heterogeneity implies price convergence, which is the standard result of the literature. Next, the introduction of trade-cost heterogeneity limits this price convergence, but tends not to reverse it. Further, if trade reform takes the form of fixed cost cuts, then there will be no price convergence. Finally, when both features are combined, the model predicts actual price divergence driven by goods market integration. 
While these features are useful theoretical devices for explaining the range of price and quantity evidence in the empirical literature, we also suspect that they have relevance for recent episodes of integration. It appears likely that recent episodes of integration have involved significant reductions in fixed cost components, beyond tariff cuts or other costs that depend directly on the number of units traded. Regarding NAFTA, McDaniel and Agama (2003) note "Tariff cuts were an important component of the agreement but the non-tariff-related provisions were arguably just as important in expanding economic ties among the members.” Examples include creation of dispute resolution mechanisms, provisions to protect foreign investment property rights, and protection of intellectual property rights. EMU might also involve significant fixed-cost reductions, in that it eliminates the need to have a unit for operations in the foreign exchange market to arrange currency hedging. Moreover, it is common to analyze the benefits of monetary union in terms of a monetary model with shoe leather costs, where the monetary arrangement affects the cost of going to the foreign exchange market, and the latter is a fixed cost not depending on the volume of transactions (see Rodriguez, 2002 for an example).

However, given that large fixed cost cuts were likely related to earlier EU integration, when there appears to have been positive price convergence, we suspect that fixed costs by themselves cannot provide a full explanation for the patterns in the data. Most integration episodes likely involve a combination of both per-unit and fixed cost cuts. In addition, the characteristics of new entrants to trade may also vary over time and across integration episodes. This calls for further microeconomic research on the characteristics of newly traded goods.

Our theoretical research also raises a basic question regarding the appropriate metric for gauging international integration policies, analogous to that discussed in Feenstra (1994) for computing import price indexes when estimating import demand functions. Most past research has seemed to prefer price-based measures, due to fundamental problems with quantity-based alternatives. As Engel and Rogers (1998) note, the problem with using trade flows as a measure is that the amount of trade depends also on things like factor endowments and opportunities for scale economies. So the fact that impediments to trade are small may not necessarily imply that the volume of trade will be large. Price measures do not have this problem, but our model indicates that they might suffer from other fundamental problems. Firstly, certain types of trade reforms may have minimal or no impact on price decisions and international price wedges, even while they affect how much is traded. Secondly, if integration takes place at the extensive margin, especially if new goods are different from those previously traded, standard price metrics may be misleading. ${ }^{24}$ This indicates the need for further research to find alternative metrics of international economic integration.

\footnotetext{
${ }^{24}$ Feenstra (1994), for example, suggests the idea of assigning an infinite value for prices of goods in periods where they are not available to consumers in a country.
} 


\section{References}

Anderson, James E. and Eric van Wincoop, 2004, “Trade Costs,” Journal of Economic Literature 42, 691-751.

Atkeson, Andrew and Ariel Burstein, 2005. “Trade Costs, Pricing to Market, and International Relative Prices,” mimeo, University of California at Los Angeles.

Baye, Michael R., Rupert Gatti, Paul Kattuman, and John Morgan, 2002. “Online Pricing and the Euro Changeover: Cross-Country Comparisons,” Judge Institute of Management Research Paper in Management Studies 17/2002, University of Cambridge.

Benassy, J.P. 1996. “Taste for Variety and Optimum Production Patterns in Monopolistic Competition,” Economic Letters, 52, 41-47.

Bergin, Paul R. and Robert C. Feenstra, 2001. "Pricing to Market, Staggered Contracts, and Real Exchange Rate Persistence,” Journal of International Economics, 54, 333-359.

Bergin, Paul R., Reuven Glick and Alan Taylor, 2004. "Productivity, Tradability, and the LongRun Price Puzzle,” NBER Working paper no. 10569.

Bun, Maurice and Franc Klaassen. 2002. “Has the Euro Increased Trade?” Tinbergen Institute Discussion paper no. 108/2.

Crucini, Mario J. and Mototsugu Shintani, 2004. "Persistence in Law-of-One-Price Deviations: Evidence from Micro-data" Vanderbilt University working paper.

Crucini, Mario J., Chris I. Telmer and Marios Zachariadis, 2001, "Understanding European Real Exchange Rates,” forthcoming in American Economic Review.

Engel, Charles, 1999, “Accounting for Real Exchange Rate Changes,” Journal of Political Economy, 107 June, 507-538.

Engel, Charles and John H. Rogers, 1996, “How Wide is the Border,” American Economic Review 86, 1112-1125.

Engel, Charles and John H. Rogers, 1998, "Relative Price Volatility: What Role Does the Border Play?” International Finance Discussion paper 623. Board of Governors of the Federal Reserve System.

Engel, Charles and John H. Rogers, 2004. “European Product Market Integration after the Euro,” Economic Policy, 39, 347-384.

Feenstra, Robert, 1994. "New Product Varieties and the Measurement of International Prices," American Economic Review, 84(1), 157-177.

Feenstra, Robert, 2003. “A Homothetic Utility Function for Monopolistic Competition Models, Without Constant Price Elasticity,” Economic Letters, 78, 79-86.

Funke Michael and Ralf Ruhwedel, 2003. “Trade, Product Variety and Welfare: A Quantitative Assessment for the Transition Economies in Central and Eastern Europe,” Bank of Finland Institute for Economies in Transition Discussion Paper 17/2003. 
Ghironi, Fabio, and Marc J. Melitz, 2004. "International Trade and Macroeconomic Dynamics with Heterogeneous Firms,” NBER Working paper no. 10540.

Globerman, Steven and Paul Storer, 2003, "Did the Canada - U.S. Free Trade Agreement Affect Economic Integration?” working paper, Western Washington University

Goldberg, Pinelopi and Frank Verboven, 2005. "Market Integration and Convergence to the Law of One Price: Evidence from the European Car Market,” Journal of International Economics, 65, 49-73.

Hillberry, Russell and Christine McDaniel. July 2002. “A Decomposition of North American Trade Growth since NAFTA.” US International Trade Commission working paper 2002$12-\mathrm{A}$.

HM Treasury, 2003. Euro 2003: EMU and Trade.

Hummels, David, 1999. "Toward a Geography of Trade Costs," working paper, Purdue University.

Hummels, David, 2001. “Time as a Trade Barrier,” working paper, Purdue University.

Hummels, David and Peter Klenow, 2005. “The Variety and Quality of a Nation’s Exports,” American Economic Review, 95, 704-723.

Imbs, Jean and Haroon Mumtaz, Rorten O. Ravn, and Helene Rey, 2004. "Price Convergence: What's on TV?" mimeo.

Jaimovich, Nir, 2004. "Firm Dynamics, Markup Variations, and the Business Cycle," mimeo, University of California at Santa Cruz.

Kehoe, Timothy. 2003. "An Evaluation of the Performance of Applied General Equilibrium Models of the Impact of NAFTA.” Research Department Staff Report, Federal Reserve Bank of Minneapolis.

Kehoe, Timothy J., and Kim J. Ruhl, 2002. "How Important is the New Goods Margin in International Trade?” working paper, University of Minnesota.

Lutz, Matthias, 2002. "Price Convergence under EMU? First Estimates,” working paper, Institute of Economic, University of St. Gallen.

McDaniel, Christine A. and Laurie-Ann Agama, 2003. "The NAFTA Preference and US-Mexico Trade: Aggregate-Level Analysis,” World Economy, 26, 939-967.

Melitz, Marc. 2003. “The Impact of Trade on Intra-Industry Reallocations and Aggregate Industry Productivity,” Econometrica, 71, 1695-1726.

Obstfeld, Maurice and Kenneth Rogoff, 2000. "The Six Major Puzzles in International Macroeconomics: Is there a Common Cause?” in Ben Bernanke and Kenneth Rogoff, eds., NBER Macroeconomics Annual, Cambridge: MIT press, 339-390.

Rodriquez, Hugo, 2002. "Monetary Union and the Transaction Cost Savings of a Single Currency," Review of International Economics, 10, 263-277. 
Rose, Andrew, 2000. "One Money, One Market: The Effect of Common Currencies on Trade," Economic Policy 15 (April), 7-33.

Ruhl, Kim J., 2003. "Solving the Elasticity Puzzle in International Economics” mimeo, Univ. Minnesota. 


\section{Appendix}

\section{A.1. Derivation of Consumption Aggregate Expression (1) with Endogenous Bias Weights}

To derive (1), define consumption by domestic residents of the home good and foreign traded good as $c_{H i}, i \in[0,1]$, and $c_{F T i}, i \in\left[0,1-n^{*}\right]$, respectively. We index all goods available for consumption in the domestic country by $j$ on the interval $\left[0,2-n^{*}\right]$, and order consumption as $c_{j}=c_{H i}$ for $j=i \in[0,1]$, and $c_{j}=c_{F i}$ for $j=i+1, j \in\left[1,2-n^{*}\right], i \in\left[0,1-n^{*}\right]$. Accordingly, assuming the elasticity of substitution between all varieties, domestic or foreign, is the constant $\phi$, we define aggregate consumption as

$$
\begin{aligned}
C^{\frac{\phi-1}{\phi}} & =\left(\frac{1}{2-n^{*}}\right)^{\frac{1}{\phi}}\left[\int_{0}^{1}\left(c_{i}\right)^{\frac{\phi-1}{\phi}} d i+\int_{1}^{2-n^{*}}\left(c_{i}\right)^{\frac{\phi-1}{\phi}} d i\right] \\
& =\left(\frac{1}{2-n^{*}}\right)^{\frac{1}{\phi}}\left(\frac{1}{1}\right)^{\frac{1}{\phi}} \int_{0}^{1}\left(c_{i}\right)^{\frac{\phi-1}{\phi}} d i+\left(\frac{1-n^{*}}{2-n^{*}}\right)^{\frac{1}{\phi}}\left(\frac{1}{1-n^{*}}\right)^{\frac{1}{\phi}} \int_{1}^{2-n^{*}}\left(c_{i}\right)^{\frac{\phi-1}{\phi}} d i \\
& =\left(\frac{1}{2-n^{*}}\right)^{\frac{1}{\phi}}\left(C_{H}\right)^{\frac{\phi-1}{\phi}}+\left(\frac{1-n^{*}}{2-n^{*}}\right)^{\frac{1}{\phi}}\left(C_{F T}\right)^{\frac{\phi-1}{\phi}} \\
& =\left(\theta\left[n^{*}\right]\right)^{\frac{1}{\phi}}\left(C_{H}\right)^{\frac{\phi-1}{\phi}}+\left(1-\theta\left[n^{*}\right]\right)^{\frac{1}{\phi}}\left(C_{F T}\right)^{\frac{\phi-1}{\phi}}
\end{aligned}
$$

where $\theta\left[n^{*}\right] \equiv \frac{1}{2-n^{*}}, \quad 1-\theta\left[n^{*}\right] \equiv \frac{1-n^{*}}{2-n^{*}}, \quad 0 \leq \theta\left[n^{*}\right] \leq 1$.

\section{A.2. Derivation of Labor Market Equilibrium Condition (26)}

Labor market equilibrium in the domestic country requires that labor employed in production of nontraded and traded home goods plus labor employed to cover the fixed costs of exporting equal the (exogenous) domestic labor supply $L_{H}:{ }^{25}$

$$
\int_{0}^{n} l_{H i} d i+\int_{n}^{1} l_{H i} d i+(1-n) f_{X}=L_{H}
$$

Substituting for $l_{H i}$ with the production function (13):

$$
\begin{aligned}
& \int_{0}^{n} \frac{y_{H i}}{A_{i}} d i+\int_{n}^{1} \frac{y_{H i}}{A_{i}} d i+(1-n) f_{X}=L_{H} \text { or } \\
& \int_{0}^{n} \frac{C_{H i}}{A_{i}} d i+\int_{n}^{1} \frac{c_{H i}+\frac{C_{H i}^{*}}{1-\tau_{i}}}{A_{i}} d i+(1-n) f_{X}=L_{H}
\end{aligned}
$$

since $y_{H i}=c_{H i}$ for $i \in[0, n], \quad y_{H i}=c_{H i}+\frac{c_{H i}^{*}}{1-\tau_{i}}$ for $i \in[n, 1]$. Substituting with $c_{H i} / C_{H}=\left(p_{H i} / P_{H}\right)^{-\phi}$ and $c_{H i}^{*} / C_{H T}^{*}=(1-n)^{-1}\left(p_{H i}^{*} / P_{H T}^{*}\right)^{-\phi}$ gives

\footnotetext{
${ }^{25}$ When all home goods are nontraded, i.e. $n=1$, then no labor is employed to cover fixed costs of exporting.
} 


$$
\int_{0}^{n} \frac{C_{H}}{A_{i}}\left(\frac{p_{H i}}{P_{H}}\right)^{-\phi} d i+\int_{n}^{1}\left(\frac{1}{A_{i}}\right)\left[C_{H}\left(\frac{p_{H i}}{P_{H}}\right)^{-\phi}+\frac{1}{1-\tau_{i}}\left(\frac{1}{1-n}\right) C_{H T}^{*}\left(\frac{p_{H i}^{*}}{P_{H T}^{*}}\right)^{-\phi}\right] d i+(1-n) f_{X}=L_{H}
$$

Using (14) and (15) in turn to substitute for $p_{H i}, p_{H i}^{*}$ and (17) and (20) to substitute for the definitions of $\tilde{A}, \tilde{A}_{1-\tau) T}[n]$ gives

$$
W=\left(L_{H}-(1-n) f_{X}\right)^{-1 / \phi}\left(\frac{\phi-1}{\phi}\right)\left[\left(\frac{P_{H} C_{H}}{\left(P_{H}\right)^{1-\phi}}\right)(\tilde{A})^{\phi-1}+\left(\frac{P_{H T}^{*} C_{H T}^{*}}{\left(P_{H T}^{*}\right)^{1-\phi}}\right)\left(\tilde{A}_{1-\tau) T}[n]\right)^{\phi-1}\right]^{\frac{1}{\phi}}
$$

Substituting for $P_{H}, P_{H T}^{*}$ with (23), (24) and canceling terms gives

$$
W=\left(L_{H}-(1-n) f_{X}\right)^{-1 / \phi}\left(\frac{\phi-1}{\phi}\right)\left[\left(\frac{P_{H} C_{H}}{\left(\frac{\phi}{\phi-1} \frac{W}{\tilde{A}}\right)^{1-\phi}}\right)(\tilde{A})^{\phi-1}+\left(\frac{P_{H T}^{*} C_{H T}^{*}}{\left(\frac{\phi}{\phi-1} \frac{W}{\tilde{A}_{(1-\tau) T}[n]}\right)^{1-\phi}}\right)\left(\tilde{A}_{(1-\tau) T}[n]\right)^{\phi-1}\right]
$$

which reduces to (26).

\section{A.3. Model Implications for Trade Volume}

Balanced trade (see (27)) implies that exports and imports as ratios of total aggregate consumption are equal:

$$
\frac{P_{H T}^{*} C_{H T}^{*}}{P C}=\frac{P_{F T} C_{F T}}{P C}
$$

From the relative demand conditions ((11) and its foreign counterpart ):

$$
\frac{P_{H T}^{*} C_{H T}^{*}}{P C}=\left(1-\theta^{*}[n]\right)\left(\frac{P_{H T}^{*}}{P^{*}}\right)^{1-\phi}, \frac{P_{F T} C_{F T}}{P C}=\left(1-\theta\left[n^{*}\right]\right)\left(\frac{P_{F T}}{P}\right)^{1-\phi}
$$

implying that exports relative to consumption — which equals GDP in our single period model— depends on two factors: the relative import price for foreign residents $P_{H T}^{*} / P^{*}$ and the (ii) foreign bias coefficient for imported home goods $1-\theta^{*}[n]$. A decrease in the relative price of imports and/or an increase in bias towards imports raises the home country's exports.

How does trade liberalization affect exports? We proceed by considering first a reduction in iceberg costs and then a reduction in fixed costs. We assume a symmetric steady state which, because the foreign aggregate price level is normalized to unity, implies $P=P^{*}=1$. We also assume that changes are symmetric across countries and lead to equal declines in $n, n *$ and hence increases in the number of tradable varieties. Because of the symmetric nature of the experiment, relative aggregate prices remain constant and equal to unity as well. Hence we may infer the change in relative prices solely from the change in $P_{H T}^{*}$ given by (24):

$$
P_{H T}^{*}=\left(\frac{\phi}{\phi-1}\right) \frac{W}{\tilde{A}_{(1-\tau) T}[n]}
$$

For reference, we express this price in terms of the relevant productivity averages when productivity is heterogeneous 


$$
P_{H T}^{*}=\frac{\phi}{\phi-1}\left(\frac{W}{\alpha_{1-\tau} \alpha_{A} \widetilde{\beta}_{A T}[n]}\right),
$$

and when transport costs are heterogeneous

$$
P_{H T}^{*}=\frac{\phi}{\phi-1}\left(\frac{W}{\alpha_{1-\tau} \alpha_{A} \widetilde{\beta}_{(1-\tau) T}[n]}\right) .
$$

A fall in iceberg costs (increase in $\alpha_{1-\tau}$ ) directly reduces the price of goods exported to foreign residents, increases demand, and raises the home country's level of exports. But there is an opposing effect, as falling $n$ and increased trade at the extensive margin imply goods with either lower effective productivity or higher transport costs become traded, raising the average price of imported goods. ${ }^{26}$ Wages $W$ rise as well because of increased demand for labor to produce the greater export volume. The effect on $\theta^{*}$ tends also to raise exports: as more varieties become traded, the weight placed on imported goods in the foreign price index increases, and the relative demand by foreign residents for imported goods in their consumption basket rises. ${ }^{27}$

With a fixed cost reduction, there is no direct effect on the relative price of goods exports to foreigners. But the decline in $n$ also implies goods with lower effective productivity or higher transport costs become traded, raising the average price of exported goods. ${ }^{28}$ In addition, $W$ falls in this case since less labor is needed to cover the fixed costs of exporting. The effect on $\theta^{*}$ works in the direction of raising home exports, as the increase in imported varieties raises the demand by foreigners for home country exports.

The theoretical ambiguities of the effects of trade liberalization on trade volume shares are resolved in the simulation analysis reported in Section V.

\footnotetext{
${ }^{26}$ Mathematically, since $\partial \widetilde{\beta}_{A T} / \partial n>0, \partial \widetilde{\beta}_{(1-\tau) T} / \partial n>0$, the fall in $n$ implies that $\widetilde{\beta}_{A T}[n], \widetilde{\beta}_{(1-\tau) T}[n]$ both decline.

${ }^{27}$ Since $\partial \theta^{*} / \partial n>0$ (recall $\theta^{*}[n]=1 /(2-n)$ ), a decrease in $n$, i.e. an increase in tradables varieties, decreases $\theta^{*}$ and raises $1-\theta^{*}$.

${ }^{28}$ Mathematically, since $\partial \widetilde{\beta}_{A T} / \partial n>0, \partial \widetilde{\beta}_{(1-\tau) T}^{*} / \partial n>0$, the fall in $n$ implies the terms in the denominator $\widetilde{\beta}_{A T}[n], \widetilde{\beta}_{(1-\tau) T}[n]$ decline.
} 
Table 1: Price dispersion response to integration

\begin{tabular}{lccc}
\hline & \multicolumn{3}{c}{ Change in price dispersion } \\
\cline { 3 - 4 } Country pairs or region & $1990-1994$ & $1994-1998$ & $1998-2004$ \\
\hline & & & \\
Euro zone, all country pairs & -8.70 & -0.14 & 3.02 \\
Core-core pairs & -4.49 & 0.40 & 4.14 \\
Peripheral-core pairs & -11.11 & -0.54 & 2.44 \\
Peripheral-peripheral pairs & -24.34 & -1.70 & -0.91 \\
\hline & & & \\
& $1990-1994$ & $1994-2001$ & \\
\hline North America, all country pairs & -9.11 & 7.49 & \\
Mexico-Canada & -31.95 & 21.78 & \\
Mexico-US & -27.95 & 16.86 & \\
US-Canada & -2.46 & 3.95 & \\
\hline
\end{tabular}

Notes: Positive values imply price divergence; negative values imply price convergence. Peripheral countries in the eurozone are Finland, Ireland, Portugal, Spain; core countries are Austria, Belgium, France, Germany, Italy, Luxemburg, Netherlands. Calculations are based on price differences across cities. Since some countries are represented by more than one city, the reported dispersion figures for all country pairs differ from the average of figures for the subset pairs.

Data sources: Economist Intelligence Unit Citybase data and authors' calculations. See Engel and Rogers (2004) for the cities used and the product items included in each goods category.

Table 2: Trade response to integration.

\begin{tabular}{|c|c|c|c|c|c|c|}
\hline \multirow{2}{*}{$\begin{array}{l}\text { Exporting } \\
\text { Country }\end{array}$} & \multirow{2}{*}{$\begin{array}{l}\text { Importing Country } \\
\text { or Region }\end{array}$} & \multicolumn{2}{|c|}{$\begin{array}{l}\text { Least traded goods, as } \\
\text { share of total exports }\end{array}$} & \multicolumn{2}{|c|}{$\underline{\text { Total exports (mil\$) }}$} & \multirow{2}{*}{$\begin{array}{l}\text { Increase in least } \\
\text { traded goods } \\
\text { exports/ increase } \\
\text { in total exports }\end{array}$} \\
\hline & & 1990 & 2000 & 1990 & 2000 & \\
\hline Sweden & EU & 0.10 & 0.17 & 40959 & 44862 & 2.02 \\
\hline Italy & EU & 0.10 & 0.14 & 111485 & 124438 & 1.44 \\
\hline Portugal & EU & 0.10 & 0.19 & 13607 & 17727 & 0.86 \\
\hline France & EU & 0.10 & 0.13 & 116917 & 190043 & 0.35 \\
\hline UK & EU & 0.10 & 0.14 & 88793 & 153943 & 0.34 \\
\hline \multirow[t]{2}{*}{ Spain } & EU & 0.10 & 0.16 & 40629 & 71384 & 0.25 \\
\hline & & 1989 & 1999 & 1989 & 1999 & \\
\hline Canada & Mexico & 0.10 & 0.42 & 525 & 953 & 0.99 \\
\hline Mexico & Canada & 0.10 & 0.28 & 1578 & 5825 & 0.41 \\
\hline Mexico & US & 0.10 & 0.17 & 27590 & 101842 & 0.25 \\
\hline US & Mexico & 0.10 & 0.16 & 24969 & 80342 & 0.24 \\
\hline \multicolumn{7}{|c|}{$\begin{array}{l}\text { Note: Increase in least traded goods exports relative to increase in total exports defined as col5= }[\mathrm{col} 2 * \operatorname{col} 4- \\
\left.(\operatorname{co11})^{*}(\operatorname{col} 3)\right] /[\operatorname{col} 4-\mathrm{col} 3] .\end{array}$} \\
\hline
\end{tabular}


Table 3: OLS estimates: Change in bilateral price dispersion in euro area, 1998-2002

(1)

\begin{tabular}{lcr} 
ExtMargin & 0.12 & 0.44 \\
& $(0.22)$ & $(0.22)$ \\
ExtMargin*Dum_CC & & 0.33 \\
& & $(0.12)$ \\
ExtMargin*Dum_PP & & -0.25 \\
& & $(0.13)$ \\
Constant & 0.01 & -0.04 \\
& $(0.03)$ & $(0.03)$ \\
\hline R-squared & 0.01 & 0.25 \\
No. of country pairs & 46 & 46
\end{tabular}

$0.44 * *$

$0.33 * * *$

$-0.25 *$

46

Notes: OLS estimation, where the dependent variable is the change in bilateral price dispersion over the period 1998-2002 across (46) individual country pairs in the eurozone. ExtMargin, the extensive margin variable for each country pair, is defined as the share of total bilateral trade in 2002 of the ("least traded") goods that accounted for $10 \%$ of this trade in 1998. Dum_CC and Dum_PP are dummies for country pairs in which both are core countries or peripheral countries, respectively; see notes to Table 2. Standard errors in parentheses. Variables significant at $10 \%$, $5 \%$, and $1 \%$ indicated by $*, * *$, and $* * *$, respectively.

Data sources: price dispersion figures based on EIU citybase data. Extensive margin figures based on bilateral trade data from OECD International Trade by Commodity Statistics, SITC rev. 3, disaggregated to the 4 digit level.

Table 4: Simulation results: Cut in per unit costs, with productivity heterogeneity

\begin{tabular}{lccc}
\hline & $\begin{array}{c}\text { steady } \\
\text { state }\end{array}$ & $\begin{array}{c}\text { \% change, } \\
\text { endogenous } n\end{array}$ & $\begin{array}{c}\text { \% change, } \\
\text { exogenous } n\end{array}$ \\
\cline { 2 - 4 }$n$ & 0.50 & -1.80 & 0.00 \\
Export share $^{1}$ & 0.33 & 3.92 & 3.40 \\
Extensive share $^{2}$ & -- & 0.20 & 0.00 \\
$P_{H T}^{*} / P_{H T}$ & 1.11 & -1.00 & -1.00 \\
\hline
\end{tabular}

${ }^{1}$ Export share: value of exports as ratio to GDP

${ }^{2}$ Extensive share: fraction of new import value due to new entrants

Calibration: $\beta_{A}=1, \alpha_{A}=0.5, \beta_{1-\tau}=0, \alpha_{1-\tau}=0.9, \phi=6, f_{X}=0.056$. 
Table 5: Simulation results: Cut in per unit costs, with transport cost heterogeneity

\begin{tabular}{lccc}
\hline & $\begin{array}{c}\text { steady } \\
\text { state }\end{array}$ & $\begin{array}{c}\text { \% change, } \\
\text { endogenous } n\end{array}$ & $\begin{array}{c}\text { \% change, } \\
\text { exogenous } n\end{array}$ \\
\cline { 2 - 4 }$n$ & 0.53 & -2.12 & 0.00 \\
Export share $^{1}$ & 0.21 & 4.88 & 4.02 \\
Extensive share $^{2}$ & -- & 0.23 & 0.00 \\
$P_{H T}^{*} / P_{H T}$ & 1.12 & -0.75 & -1.00 \\
\hline
\end{tabular}

${ }^{1}$ Export share: value of exports as ratio to GDP

${ }^{2}$ Extensive share: fraction of new import value due to new entrants

Calibration: $\beta_{A}=0, \alpha_{A}=1, \beta_{1-\tau}=1, \alpha_{1-\tau}=0.5, \phi=6, f_{X}=0.04$.

Table 6: Simulation results: Cut in fixed cost of trade, with productivity heterogeneity

\begin{tabular}{lccc}
\hline & $\begin{array}{c}\text { steady } \\
\text { state }\end{array}$ & $\begin{array}{c}\text { \% change, } \\
\text { endogenous } n\end{array}$ & $\begin{array}{c}\text { \% change, } \\
\text { exogenous } n\end{array}$ \\
\cline { 2 - 4 }$n$ & 0.50 & -5.85 & 0.00 \\
Export share $^{1}$ & 0.33 & 1.62 & 0.00 \\
Extensive share $^{2}$ & -- & 1.68 & 0.00 \\
$P_{H T}^{*} / P_{H T}$ & 1.11 & 0.00 & 0.00 \\
\hline
\end{tabular}

${ }^{1}$ Export share: value of exports as ratio to GDP

${ }^{2}$ Extensive share: fraction of new import value due to new entrants

Calibration: $\beta_{A}=1, \alpha_{A}=0.5, \beta_{1-\tau}=0, \alpha_{1-\tau}=0.9, \phi=6, f_{X}=0.056$.

Table 7: Simulation results: Cut in fixed cost of trade, with transport cost heterogeneity

\begin{tabular}{lccc}
\hline & $\begin{array}{c}\text { steady } \\
\text { state }\end{array}$ & $\begin{array}{c}\text { \% change, } \\
\text { endogenous } n\end{array}$ & $\begin{array}{c}\text { \% change, } \\
\text { exogenous } n\end{array}$ \\
\cline { 2 - 4 }$n$ & 0.53 & -5.76 & 0.00 \\
Export share $^{1}$ & 0.21 & 2.18 & 0.00 \\
Extensive share $^{2}$ & -- & 1.49 & 0.00 \\
$P_{H T}^{*} / P_{H T}$ & 1.12 & 0.69 & 0.00 \\
\hline
\end{tabular}

${ }^{1}$ Export share: value of exports as ratio to GDP

${ }^{2}$ Extensive share: fraction of new import value due to new entrants

Calibration: $\beta_{A}=0, \alpha_{A}=1, \beta_{1-\tau}=1, \alpha_{1-\tau}=0.5, \phi=6, f_{X}=0.04$. 
Fig. 1: Change in price dispersion in the euro-11

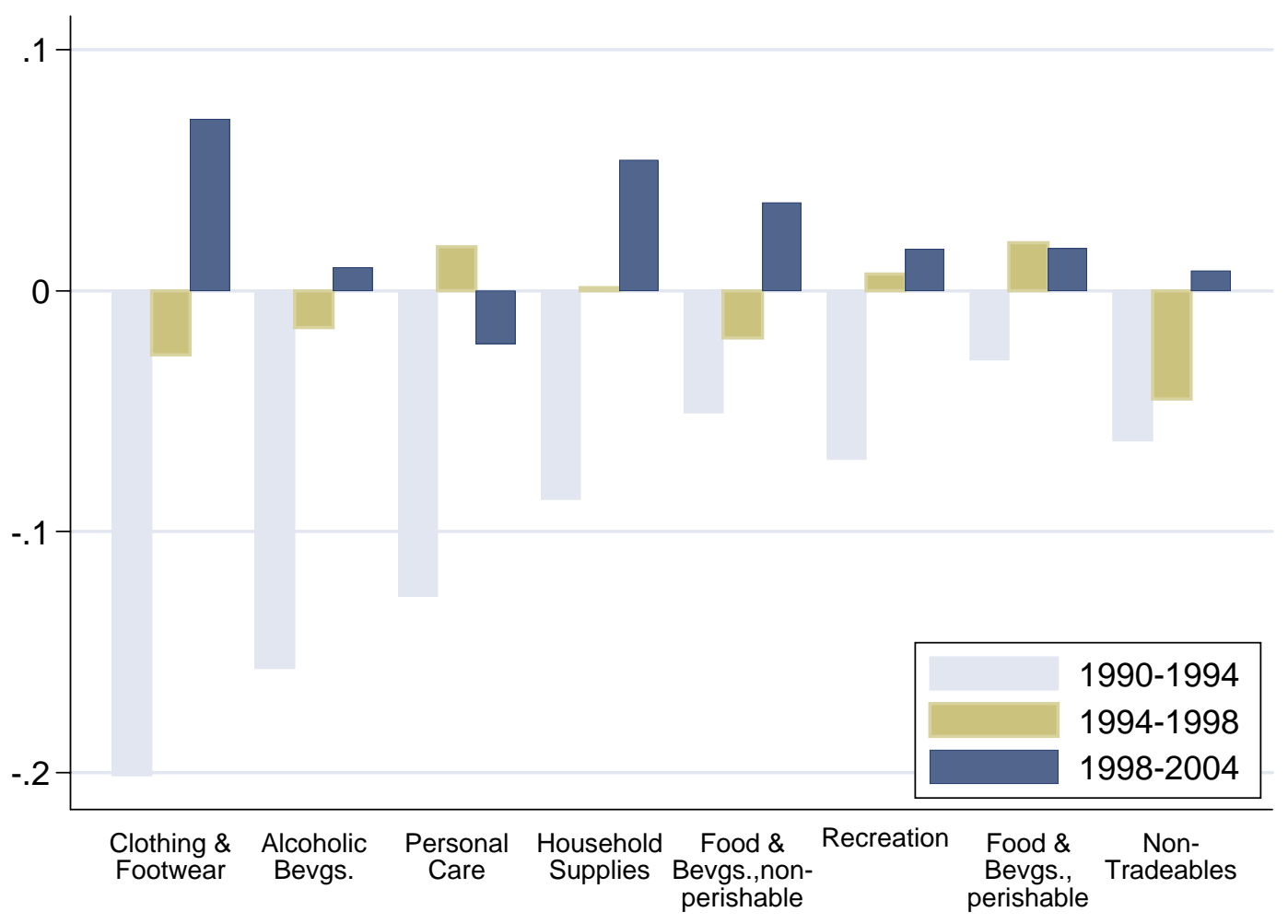

Source: Economist Intelligence Unit Citybase data and authors' calculations. See Engel and Rogers (2004) for the cities used and the product items included in each goods category. Note: positive values imply price divergence; negative values imply price convergence.

Figure 2: Summary of main model implications

\begin{tabular}{|c|c|c|c|c|c|}
\hline \multirow{3}{*}{ 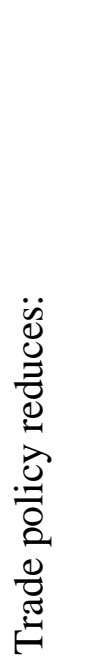 } & \multirow[b]{2}{*}{ 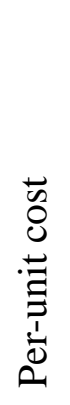 } & \multicolumn{4}{|c|}{ Heterogeneity type: } \\
\hline & & $\begin{array}{l}\text { Extensive margin: } \\
\text { Price convergence: }\end{array}$ & $\begin{array}{l}\text { SMALL } \\
\text { LARGE }\end{array}$ & $\begin{array}{l}\text { Extensive margin: } \\
\text { Price convergence: }\end{array}$ & $\begin{array}{l}\text { SMALL } \\
\text { MEDIUM }\end{array}$ \\
\hline & 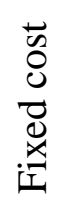 & $\begin{array}{l}\text { Extensive margin: } \\
\text { Price convergence: }\end{array}$ & $\begin{array}{l}\text { LARGE } \\
\text { ZERO }\end{array}$ & $\begin{array}{l}\text { Extensive margin: } \\
\text { Price convergence: }\end{array}$ & $\begin{array}{l}\text { LARGE } \\
\text { NEGATIVE }\end{array}$ \\
\hline
\end{tabular}


Fig. 3: Distributions in simulation with productivity heterogeneity only

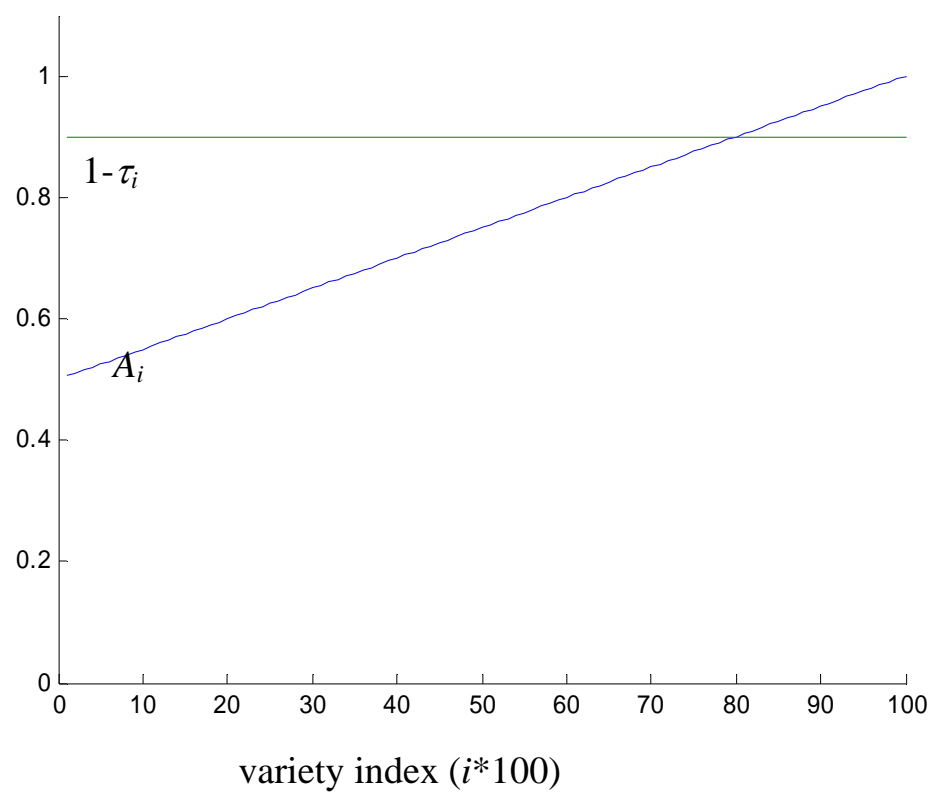

Fig. 4: Distributions in simulation with transport cost heterogeneity only

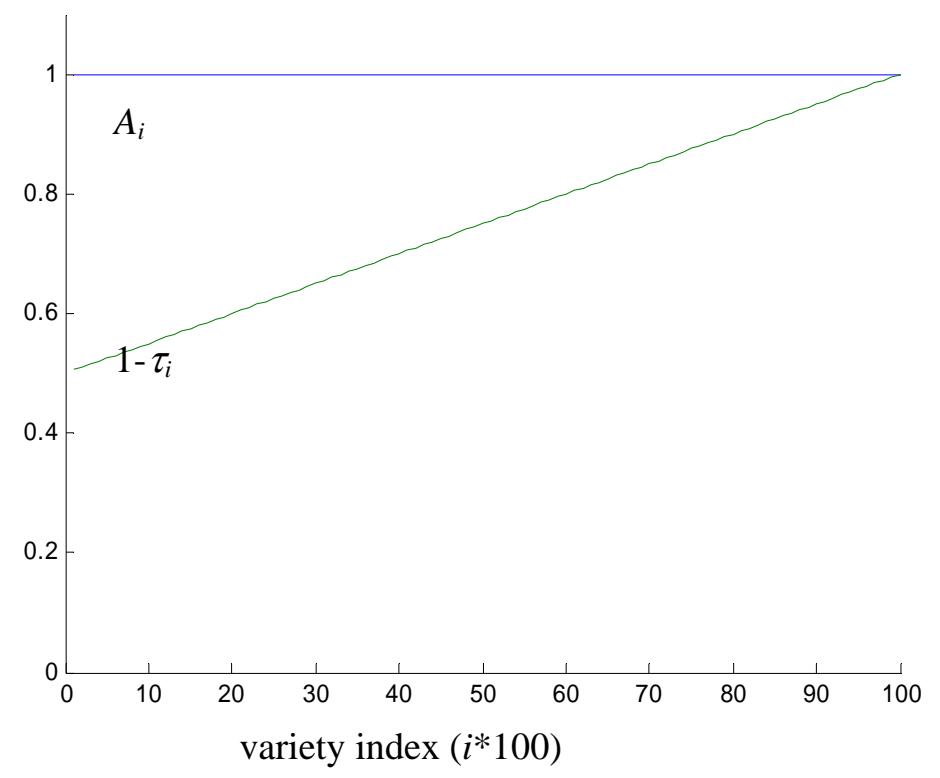

